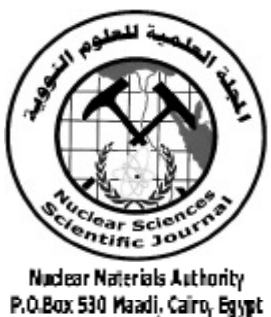

ISSN 2314-5609

Nuclear Sciences Scientific Journal

vol. 4, p 61- 83

2015

\title{
GEOLOGY, GEOCHEMISTRY AND RADIOACTIVITY OF GRANITOID ROCKS OF ABU MARW AREA, SOUTH EASTERN DESERT, EGYPT
}

\author{
ADEL H. EL-AFANDY; ABD ALRAHMAN EMBABY ${ }^{1}$ and MONA A. EL HARAIREY \\ Nuclear Materials Authority, Cairo; ' ${ }^{1}$ Fac. Sci., Damietta Univ.
}

\begin{abstract}
Abu Marw area is located in the southeastern part of the Eastern Desert, about $150 \mathrm{~km}$ south east of Aswan. The Abu Marw area is mainly covered by late Proterozoic igneous and metamorphic rocks. These basement rocks are unconformably overlain by late Cretaceous Nubian sandstones in the western and northern parts of the area. Abu Marw granitoid batholiths comprises a co-magmatic calc alkaline I type peraluminous suite of rocks ranging in composition from tonalite, granodiorite, monzogranite, syenogranite to alkali feldspar granite. The variations of some major and trace elements with $\mathrm{SiO}_{2}$ suggest a crystal fractionation model.The tonalite rocks probably had evolved within a continental arc/continental collision environment, while the granodiorite, monzogranite, syenogranite and alkali feldspar granite rocks had evolved in within plat environment.

The studied tonalite and granodiorite samples have $\Sigma$ REE lower than the average REE values (250ppm) of granitic rocks, while the monzogranite, syenogranite and alkali feldspar granite samples have $\Sigma$ REE above the average REE values of granitic rocks. Chondrite-normalized REE patterns of the considered granites display a gull-wing shape, characterized by large to moderately fractionated patterns and high LREE relative to the MREE and HREE contents. Furthermore, the studied rocks have a steadily decreasing $\mathrm{Eu} / \mathrm{Eu}^{*}$ values from the tonalite to the alkali feldspar granite with simultaneous increase in the $\Sigma \mathrm{REE}$ contents.

The average contents of $U$ and $T h$ in the different granitic rocks resemble the average contents of some international equivalent rocks. The average of $U$ contents increases with differentiation. The uranium and thorium contents in the studied granitic rocks are present in the accessory minerals particularly monazite, zircon, allanite, sphene, apatite and iron oxides, The radioactive minerals in the pegmatite anomalies are mainly zircon, uranothorite and fluorite, while in the sheared granites uranophane as secondary minerals and zircon, allanite, xenotime and uranothorite which are known as $\mathrm{U}$ and $\mathrm{Th}$ bearing minerals.
\end{abstract}

\section{INTRODUCTION}

Different schemes for classifying the granites were proposed depending on different objects of view. One scheme gave weight to relative ages (e.g. Hume 1935, El Ramly \& Akaad 1660), another emphasized type localities (e.g. Schurmann 1957), a third considered the relation to orogeneses (e.g. El Shazly 1964), and a fourth depended primar- ily on chemical composition (El Gaby 1975, and Hussein et al., 1982).

Other classifications of interest were also proposed for example, Sabet et al., (1976) and El Shatoury et al., (1984). Also, Greenberg (1981), Kabesh et al., (1987), Noweir et al., (1990) and El Sayed (1998) suggested classifications for the younger granites only. El Shazly et al., $(1965,1973,1975)$ studied the geol- 
ogy of Abu Swayel area including the studied area and published a regional geological map covering $1270 \mathrm{~km}^{2}$. Furthermore, the studied area is also included within Gabal Nasiya geological sheet (scale 1:100,000) mapped by Geological Survey of Egypt (Armanious et al., 1977). Also, Abdel Monem et al., (1991, 1996) and El Afandy (1994), Noweir et al., (1996) and Masoud (2012) studied the geology and geochemistry of Abu Marw-Um Arka area.

Abu Marw area is situated in the South Eastern Desert of Egypt, at about 150km south east of Aswan It is located between latitudes $22^{\circ} 59^{\prime}$ and $23^{\circ} 11^{\prime} \mathrm{N}$ and longtitude $33^{\circ}$ $24^{\prime}$ and $33^{\circ} 34^{\prime} \mathrm{E}$ at Wadi Abu Marw-Wadi Um Arka area. The geological, geochemical and tectonic settings as well as radioactivity of the granitoid rocks in Abu Marw area are discussed.

The present study is an attempt to clarify the genetic relation between the granitic rocks in an area covering about $650 \mathrm{~km}^{2}$.

\section{GENERAL GEOLOGY}

The Abu Marw area is mainly covered by Late Proterozoic igneous and metamorphic rocks. These basement rocks are unconformably overlain by upper Cretaceous Nubian sandstone in the western and northern parts of the area. From field investigations and petrographic description, the granitoid rocks in the studied area can be divided from the oldest to youngest into tonalite, granodiorite, monzogranite, syenogranite and alkali feldspar granite.

The tonalite rocks form the peripheral phase are exposed in curvilinear ridges along the northeastern and eastern part of batholith, (Fig. 1). They are typically foliated containing screens of the metamorphosed and foliated country rocks indicating forceful mode of intrusion characteristic of orogenic belt near active plate boundaries. The contacts between the tonalite and the surrounding metavolcanics, granodiorites, syenogranites and alkali feldspar granites are sharp contacts. The tonalites are invaded by quartz feldspar porphyrite dykes and some of them intersect each other.

Petrographically, these rocks are generally light greyish green in colour speckled with milky plagioclase feldspars. They are medium to coarse grain in size, and porphyritic texture with plagioclase phenocrysts. Microscopi-

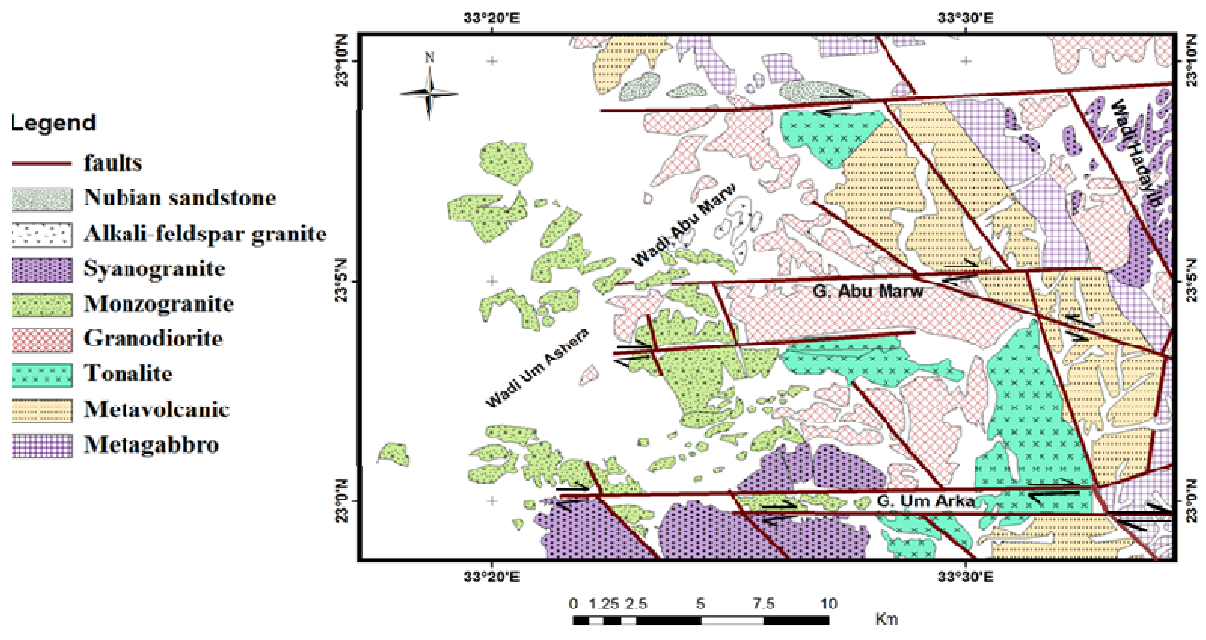

Fig.1: Geological map of Abu Marw area (Modified after El-Afandy,1994) 
cally, they are composed mainly of plagioclases, hornblende, biotite, quartz and subordinate microcline. The accessory minerals are sphene, epidote, apatite and iron oxides.

The granodiorite rocks form low relief hillocks occupying the eastern central part of the batholith due to the rapid weathering of these coarse grained rocks and the north western part of the mapped area, (Fig.1). These rocks are oriented in ENE, N-S and NW directions. These rocks are fractured to large exfoliated spheroidal boulders. They contain many tonalitic xenoliths especially near the contacts with the tonalites. The contacts between the granodiorites and the surrounding rocks are sharp contacts. These rocks are partially covered by Nubian sandstones especially in the northwestern part of the mapped area. They are invaded in the central part of the mapped area by a nearly paralled swarm dykes trending E-W and extending for about $12 \mathrm{Km}$, these dykes are mostly of quartz feldspar porphery type ranging in thickness from $3-10 \mathrm{~m}$.

These rocks are generally light greyish green in colour speckled with milky plagioclase feldspars. They are medium to coarse grain in size, and porphyritic texture with plagioclase phenocrysts. These rocks are hypidiomorphic, having myrmekitic and rapakivi textures. Microscopically, they are mainly composed of plagioclases, hornblende, biotite, quartz and subordinate microcline. The accessory minerals are zircon, sphene, apatite, allanite, muscovite and iron oxide.

The monzogranites are encountered at the central part of the granitic batholith. They surround the tonalites and granodiorites, (Fig. 1). These rocks are coarse grained and porphyritic. They cut by NNW, NW, E-W and ENE faults. The contact between the monzogranites and the surrounding tonalites, granodiorites and syenogranites are intrusive and structural contacts. They form continuous curvilinear mountains range trending E-W and scattered group of circular or oval shaped hills in the northwestern part of the mapped area. These rocks are invaded by dykes and veins.

Petrographically, these rocks are hypidiomorphic with myrmekitic texture. The monzogranite rocks are generally light pink, medium to coarse grain in size. Microscopically, they are essentially composed from quartz, microcline perthite, microcline, plagioclase and biotite, whereas sphene and annite are found as accessory minerals.

Syenogranites constitute the southern part of the mapped area (Fig. 1). They are cut by wadi Um Arka and Wadi Um Ashara. These rocks are cut by NW and E-W faults. These rocks form a continuous mountain trending EW and a scattered group of oval shape in the southwestern part of the mapped area. These rocks are fractured and invaded by many dykes ranging in composition from microgranites, basalts as well as pegmatite and quartz veins. The contacts between these rocks and the surrounding rocks are sharp contacts.

Petrographically, these granites are coarse grained and pink in colour. they are essentially composed of K-feldspar, quartz, plagioclase and biotite with minor amount of hornblende, the accessory minerals are sphene, zircon, apatite, muscovite and iron oxides, while epidote and chlorite are secondary minerals.

Alkali feldspar granites constitute a small area encountered in the central part of the mapped area (Fig.1). These rocks are pink to red in colour, equigranular and scarce in mafic minerals. They have curve linear isolated masses. The alkali feldspar granites have low to moderate elevated mountains cut by wadi Abu Marw. They occupy an area of about $9 \mathrm{~km}^{2}$. The contacts between these rocks and the surrounding older rocks are sharp.

Petrographically, this granite is medium grained with pink to red colour and displays hypidiomorphic equigranular texture. It is mainly composed of potash feldspar and quartz with subordinate plagioclase crystals and biotite as essential minerals. Muscovite, zircon, monazite and iron oxides as accessories, while chlorite and sericite are secondary 
minerals. The mafic minerals are scarce giving rise to the leucogranite type.

\section{GEOCHEMISTRY}

Thirty six samples including seven tonalite samples, five granodiorite samples, five monzogranite samples, eleven syenogranite samples and eight alkali feldspar granite samples were chemically analyzed for major oxides, some trace elements and rare earth elements. The analyses were carried out at the ACME Analytical Laboratories Ltd, Canada. The analytical results are given in Tables (1\&2).

The variations between the $\mathrm{SiO}_{2}$ and the major oxides (Figs.2-9), indicate that there is a negative correlation between $\mathrm{TiO}_{2}, \mathrm{Al}_{2} \mathrm{O}_{3}$, $\mathrm{Fe}_{2} \mathrm{O}_{3}, \mathrm{CaO}, \mathrm{MnO}$ and $\mathrm{MgO}$ with increasing $\mathrm{SiO}_{2}$, while $\mathrm{K}_{2} \mathrm{O}$ and $\mathrm{Na}_{2} \mathrm{O}$ show positive correlation with increasing $\mathrm{SiO}_{2}$. It is also clear that the series tonalite, granodiorite, monzogranite, syenogranite and alkali feldspar granite which mostly show straight line variations could represent a differentiated co-magmatic series. Also, the distribution and variation of trace elements during igneous processes can be shown by plotting their contents against $\mathrm{SiO}_{2}$ (Figs.10-16). Y, Zr, Ga, $\mathrm{Rb}$ and $\mathrm{Nb}$ exhibit an increasing trend with the increase in $\mathrm{SiO}_{2}$ from tonalite to alkali feldspar granite. The $\mathrm{Sr}$ and $\mathrm{Ba}$ show a decreasing trend from tonalite to alkali feldspar granite. The data

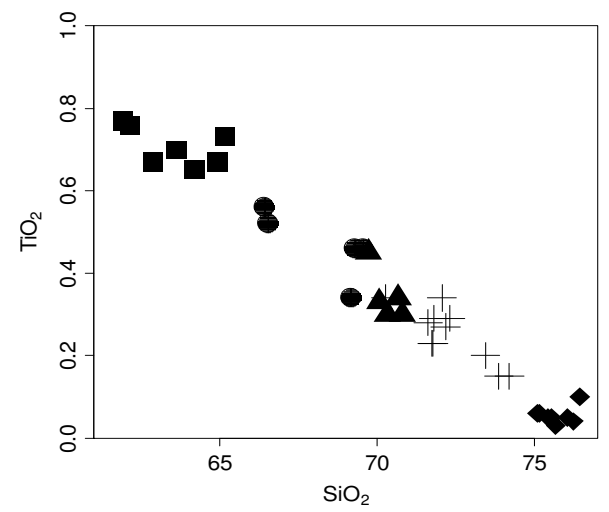

Fig. 2: Variation diagram between $\mathrm{SiO}_{2}$ and $\mathrm{TiO}_{2}$

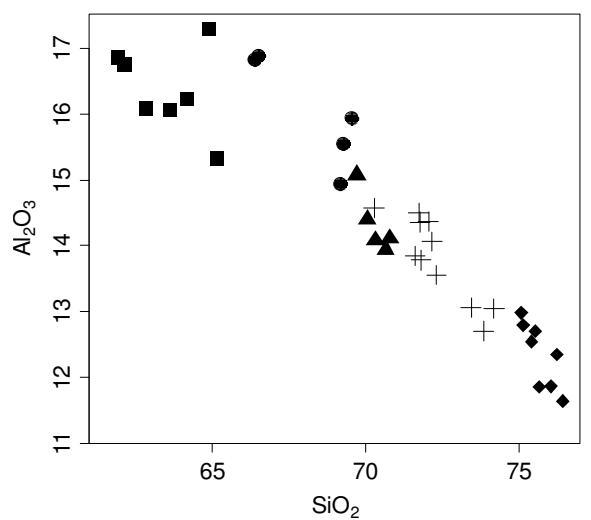

Fig.3: Variation diagram between $\mathrm{SiO}_{2}$ and $\mathrm{Al}_{2} \mathrm{O}_{3}$

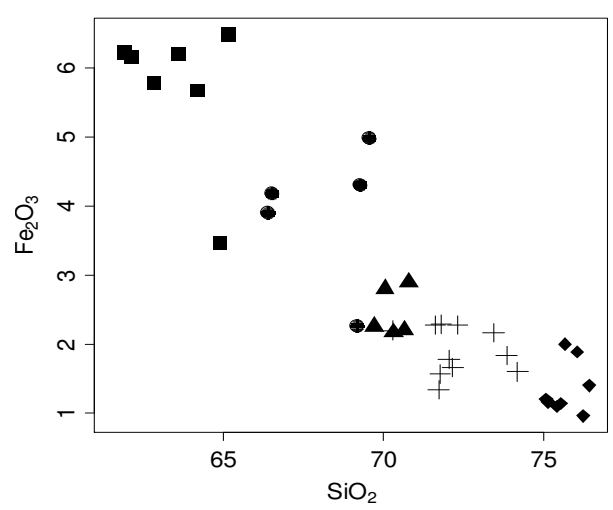

Fig.4: Variation diagram between $\mathrm{SiO}_{2}$ and $\mathrm{Fe}_{2} \mathrm{O}_{3}$

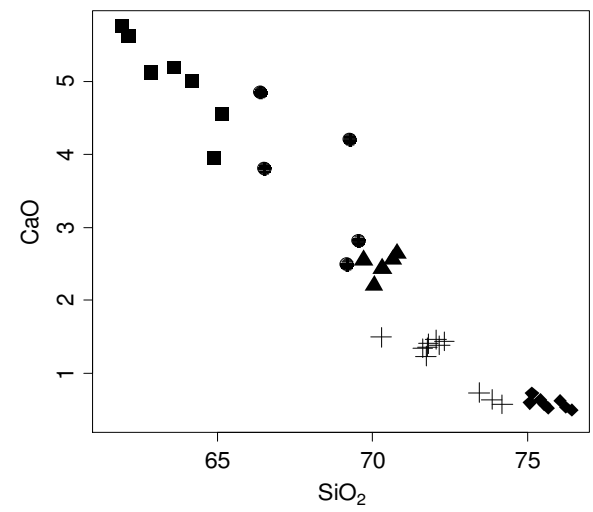

Fig. 5 : Variation diagram between $\mathrm{SiO}_{2}$ andCaO 


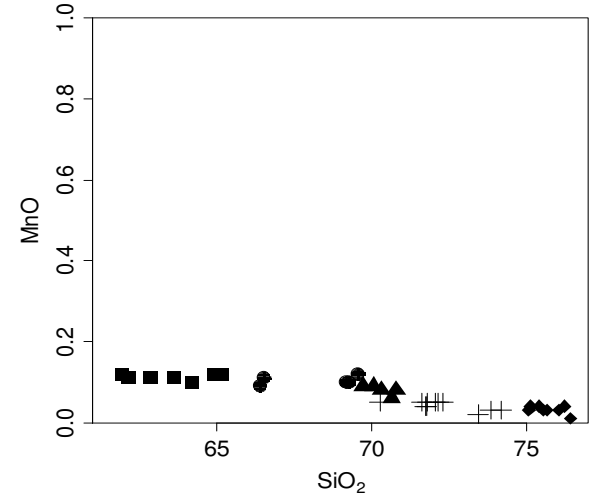

Fig.6 : Variation diagram between $\mathrm{SiO}_{2}$ and $\mathrm{MnO}$

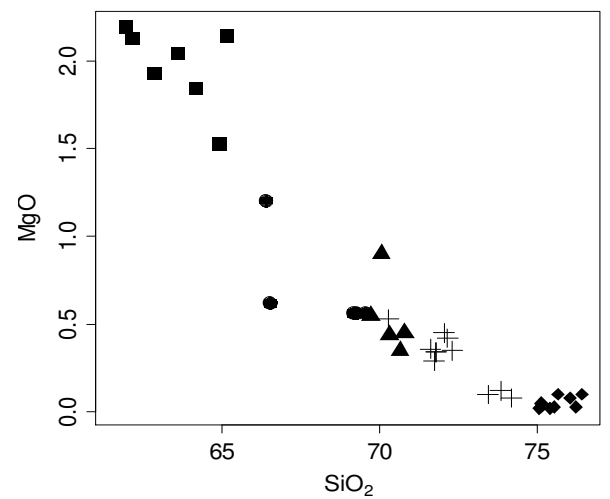

Fig.7 : Variation diagram between $\mathrm{SiO}_{2}$ and $\mathrm{MgO}$

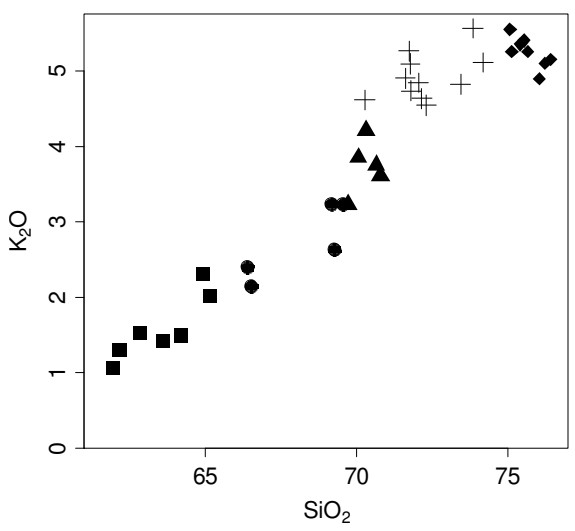

Fig.8 : Variation diagram between $\mathrm{SiO}_{2}$ and $\mathrm{K}_{2} \mathrm{O}$

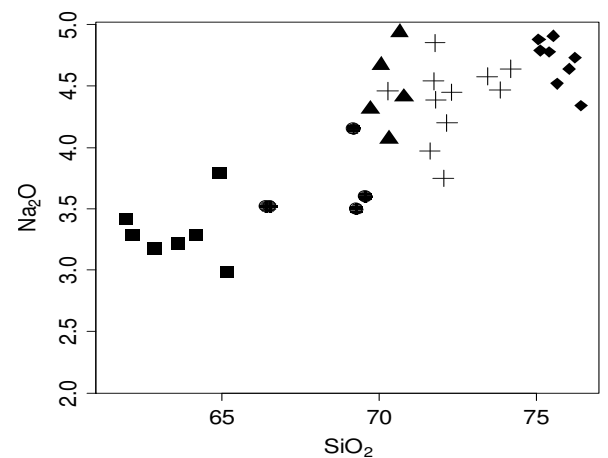

Fig. 9: Variation diagram between $\mathrm{SiO}_{2}$ and $\mathrm{Na}_{2} \mathrm{O}$ points show some scattering but the studied rock types occupy separate fields. The trends may indicate that the distribution of the trace elements was controlled by the crystallization sequence of the major minerals by magmatic processes through crystal fractionation of the tonalite-alkali feldspar granite differentiation series.

\section{Classification and Nomenclatures}

The plotting of the present granitic rocks on the Ab-An-Or normative diagram (Streckeisen, 1976) (Fig.17), shows that the analyzed data are plotted in the corresponding fields except one tonalite sample plot on the boundary between the tonalite and granodiorite field and

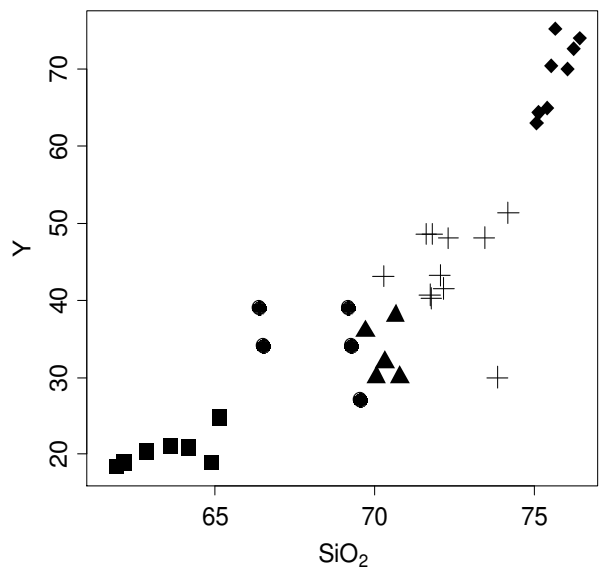

Fig.10 : Variation diagram between $\mathrm{SiO}_{2}$ and $\mathrm{Y}$ 


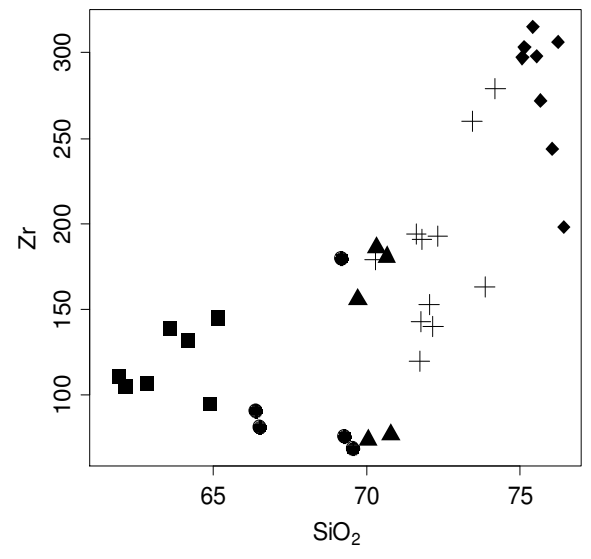

Fig.11: Variation diagram between $\mathrm{SiO}_{2}$ and $\mathrm{Zr}$

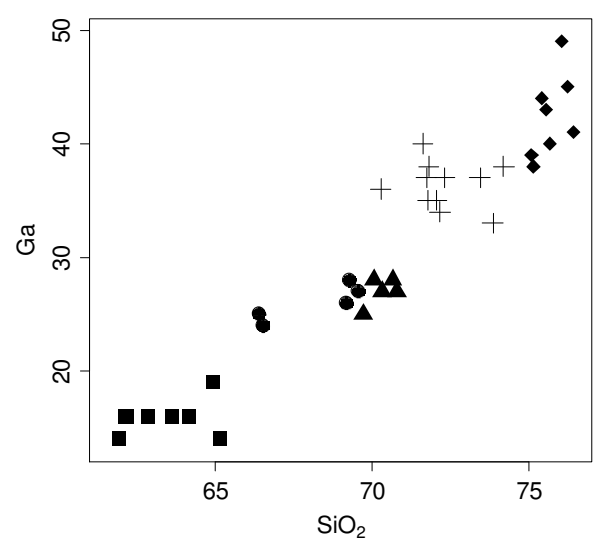

Fig. 12: Variation diagram between $\mathrm{SiO}_{2}$ and $\mathrm{Ga}$

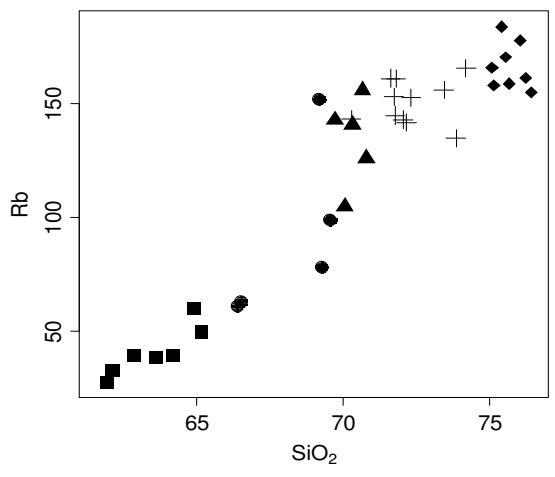

Fig.13: Variation diagram between $\mathrm{SiO}_{2}$ and $\mathrm{Rb}$

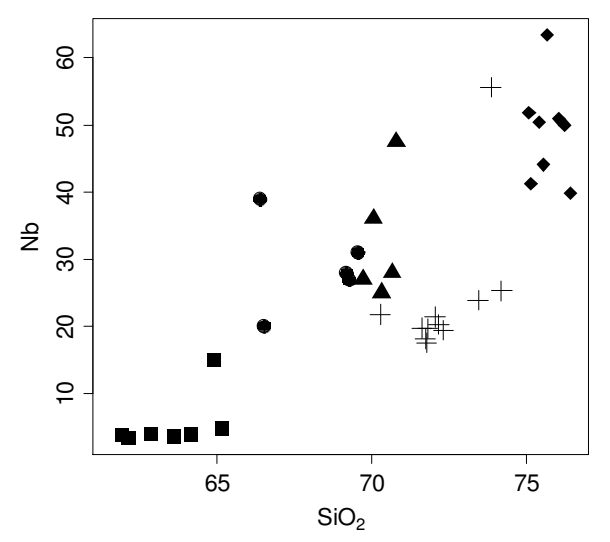

Fig.14: Variation diagram between $\mathrm{SiO}_{2}$ and $\mathrm{Nb}$

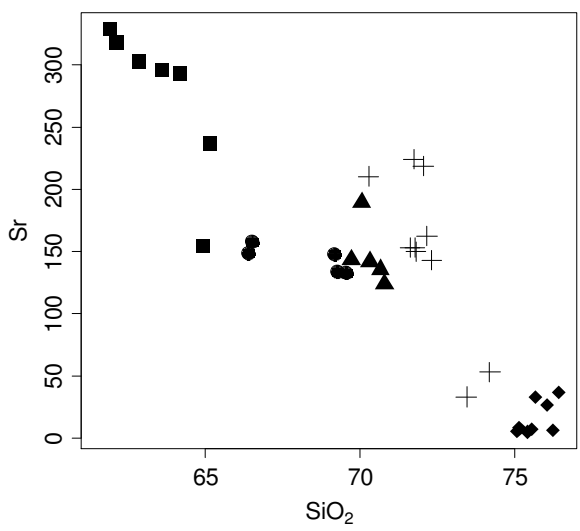

Fig.15: Variation diagram between $\mathrm{SiO}_{2}$ and $\mathrm{Sr}$

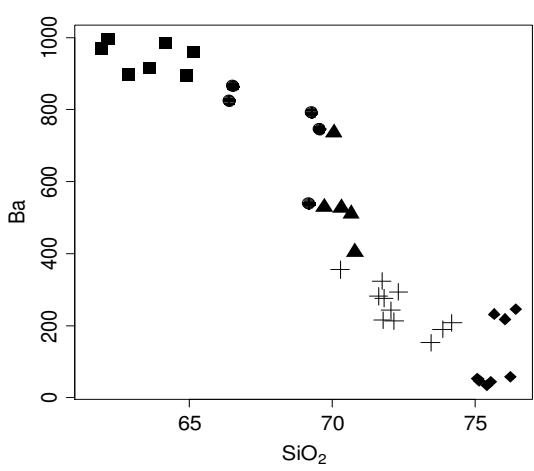

Fig.16: Variation diagram between $\mathrm{SiO}_{2}$ and $\mathrm{Ba}$ 
Table 1: Major oxides, some CIPW and trace elements analyses of the studied granitoid rocks

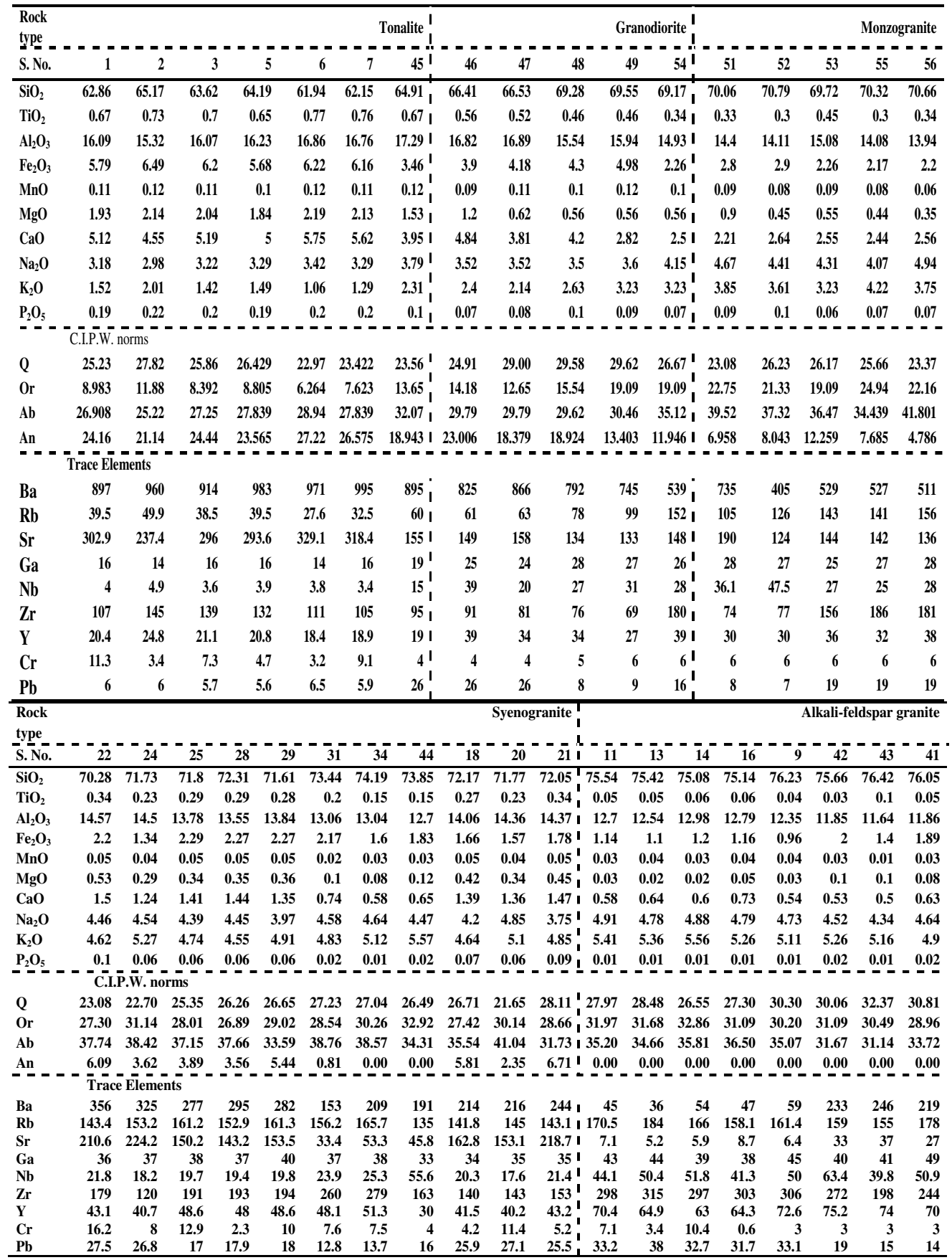


ADEL H. EL-AFANDY et al.

Table 2: Rare earth elements analyses of the studied granitoid rocks

\begin{tabular}{|c|c|c|c|c|c|c|c|c|c|c|c|c|c|c|}
\hline \multirow{2}{*}{ S.No } & & & & & & & & & & & \multicolumn{4}{|c|}{ Rare Earth Elements } \\
\hline & La & $\mathrm{Ce}$ & Pr & Nd & Sm & Eu & Gd & Tb & Dy & Ho & Er & Tm & Yb & Lu \\
\hline \multicolumn{15}{|c|}{ Tonalites } \\
\hline 1 & 21.9 & 45.24 & 5.5 & 22.8 & 4.7 & 1.3 & 3.9 & 0.6 & 3.3 & 0.5 & 1.9 & 0.3 & 2.5 & 0.4 \\
\hline 3 & 21 & 46.87 & 6 & 24.9 & 5.6 & 1.2 & 4.4 & 0.5 & 3 & 0.5 & 1.5 & 0.2 & 2.2 & 0.4 \\
\hline 5 & 42.6 & 74.39 & 8.5 & 33 & 4.9 & 1 & 3.5 & 0.4 & 2.3 & 0.3 & 0.9 & 0.1 & 1.2 & 0.2 \\
\hline 7 & 35.5 & $\mathbf{7 8 . 7 3}$ & 10.4 & 45.1 & 8.4 & 1.8 & 6.3 & 0.7 & 4.1 & 0.6 & 1.5 & 0.3 & 2.5 & 0.4 \\
\hline \multicolumn{15}{|c|}{ 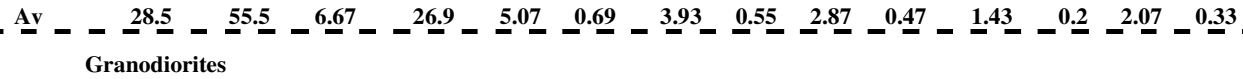 } \\
\hline 45 & 29.8 & 59.23 & 7.3 & 27.7 & 5.8 & 1 & 5.5 & 0.8 & 5.5 & 1 & 3 & 0.4 & 3.3 & 0.4 \\
\hline 46 & 28.1 & 57.77 & 6.9 & 27.1 & 5.3 & 1 & 5.6 & 0.8 & 5.5 & 1.1 & 3 & 0.4 & 3.4 & 0.5 \\
\hline 47 & 24.5 & 47.3 & 5.7 & 21.6 & 4.6 & 1.2 & 4.3 & 0.6 & 4 & 0.7 & 2.1 & 0.3 & 2.4 & 0.3 \\
\hline 49 & 28.6 & 56.96 & 6.7 & 25.6 & 5.1 & 1.1 & 4.5 & 0.6 & 3.3 & 0.6 & 1.7 & 0.3 & 2.1 & 0.3 \\
\hline 54 & 31.8 & 63.06 & 7.8 & 30.7 & 6.5 & 1.1 & 6.7 & 0.9 & 6.2 & 1.2 & 3.4 & 0.5 & 3.5 & 0.5 \\
\hline \multicolumn{15}{|c|}{$\underset{\text { Monzogranites }}{\text { Av }}-\underset{28.56}{-56.86}-6.88-26.54-5.46-1.08-5.32-0.74-4.9-0.92-2.64-0.38-2.94-0.4$} \\
\hline 51 & 50 & 89.09 & 9.8 & 33.8 & 5.9 & 0.9 & 4.8 & 0.6 & 4.1 & 0.7 & 2.3 & 0.3 & 2.8 & 0.4 \\
\hline 52 & 57.9 & 97.6 & 10.5 & 36.5 & 5.7 & 1 & 4.3 & 0.7 & 4 & 0.7 & 2.3 & 0.3 & 2.7 & 0.4 \\
\hline 53 & 39.7 & 77.5 & 9.4 & 34.7 & 6.3 & 1 & 5.6 & 0.7 & 4.4 & 0.9 & 2.8 & 0.4 & 3.1 & 0.4 \\
\hline 54 & 44.9 & 93.14 & 11.6 & 44.6 & 9.3 & 0.9 & 8.2 & 1.2 & 8.2 & 1.4 & 4.1 & 0.6 & 4.2 & 0.5 \\
\hline 55 & 50.1 & 103.9 & 12.6 & 48.4 & 9.5 & 0.9 & 7.8 & 1.2 & 7.2 & 1.4 & 3.7 & 0.5 & 3.9 & 0.6 \\
\hline 56 & 48.5 & 98.72 & 12 & 46.4 & 8.7 & 1 & 7.3 & 1.1 & 6.7 & 1.2 & 3.2 & 0.5 & 3.8 & 0.5 \\
\hline 57 & 47 & 96.96 & 12.2 & 45.6 & 9.2 & 1 & 7.8 & 1.2 & 7.5 & 1.3 & 3.8 & 0.6 & 4 & 0.6 \\
\hline 58 & 46.4 & 92.43 & 11.2 & 42.3 & 8.8 & 0.9 & 7.5 & 1 & 6.4 & 1.2 & 3.1 & 0.4 & 3.2 & 0.5 \\
\hline \multicolumn{15}{|c|}{ 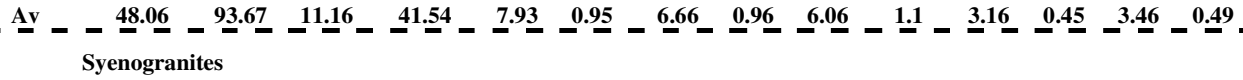 } \\
\hline 22 & 93.2 & 207.3 & 25.9 & 85.6 & 16.8 & 0.9 & 10.2 & 1.5 & 6.4 & 1.2 & 3 & 0.4 & 2.4 & 0.4 \\
\hline 24 & 98.8 & 229.6 & 29.8 & 101.4 & 19.4 & 0.8 & 12.8 & 2.1 & 8.5 & 1.6 & 3.7 & 0.5 & 2.8 & 0.4 \\
\hline 28 & 61.3 & 156.9 & 20 & 72.2 & 15.6 & 0.6 & 9 & 1.3 & 6.3 & 1 & 2 & 0.4 & 2 & 0.3 \\
\hline 29 & 82.5 & 234.8 & 28 & 96 & 20.7 & 0.7 & 11.7 & 1.6 & 8.1 & 1.4 & 3.4 & 0.5 & 2.9 & 0.4 \\
\hline 34 & 80 & 194.8 & 25.1 & 95.8 & 18.8 & 0.7 & 14.7 & 1.5 & 8.1 & 1.2 & 2.8 & 0.4 & 2.4 & 0.3 \\
\hline \multicolumn{15}{|c|}{ 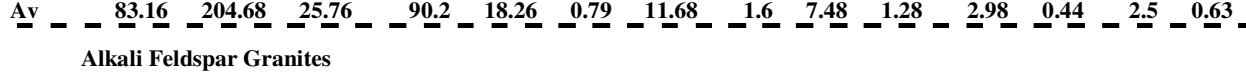 } \\
\hline 11 & 205 & 499.8 & 62.8 & 27.4 & 57 & 4.9 & 42.9 & 5.8 & 33.5 & 5.1 & 12.1 & 1.6 & 10.5 & 1.2 \\
\hline 13 & 183.5 & 422.8 & 54.6 & 229.1 & 48.1 & 3.9 & 38.2 & 4.6 & 27.7 & 4.1 & 9.9 & 1.3 & 8.4 & 1 \\
\hline 14 & 224.7 & 499.7 & 57.9 & 218.8 & 37.8 & 4 & 24.7 & 3.4 & 20 & 3.2 & 8.6 & 1.2 & 7.6 & 1 \\
\hline 16 & 175.6 & 398.5 & 49.1 & 191.6 & 35.3 & 4.1 & 25.1 & 3.3 & 20.1 & 3.3 & 9.1 & 1.2 & 7.8 & 1 \\
\hline 41 & 204.6 & 485.4 & 59.5 & 230.7 & 43.6 & 4.4 & 30.2 & 4 & 24.2 & 4.1 & 10.5 & 1.4 & 9.6 & 1.2 \\
\hline Av & 198.68 & 461.24 & 56.78 & 228.84 & 44.36 & 4.26 & 32.22 & 4.22 & 25.1 & 3.96 & 10.04 & 1.34 & 8.78 & 1.08 \\
\hline
\end{tabular}


two syenogranite samples plot in the alkali feldspar field. The same results are given from the discrimination $\mathrm{K}_{2} \mathrm{O}+\mathrm{Na}_{2} \mathrm{O}-\mathrm{SiO}_{2}$ binary diagram of Middlemost (1994), (Fig.18).

\section{Magma Type}

The plotting of Abu Marw granitoids on the $\mathrm{CaO}-\mathrm{K}_{2} \mathrm{O}-\mathrm{Na}_{2} \mathrm{O}$ ternary variation diagram of Condie, (1973) and Condie and Hunter, (1976) shows that the studied granitoid rocks plot within the calc-alkaline field of Hunter (1979), (Fig. 19).

The AFM variation diagram of Irvine and Baragar, (1971), shows that the studied

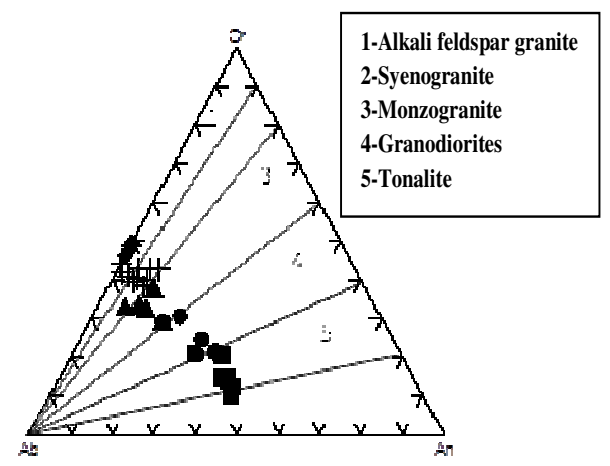

Fig.17: Ab-An-Or normative diagram of the studied granitoid rocks (According to Streckeisen, 1976)

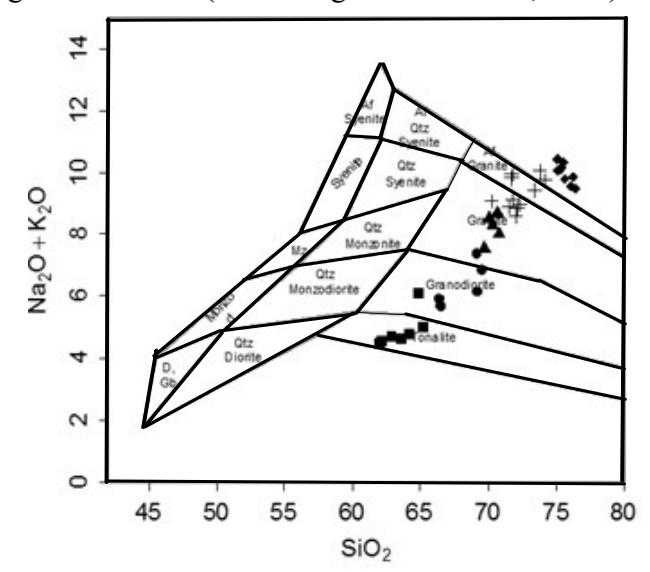

Fig. 18: $\left(\mathrm{Na} 2 \mathrm{O}+\mathrm{K}_{2} \mathrm{O}\right)-\mathrm{SiO}_{2}$ binary variation diagram of the studied granitoid rocks( According to Middlemost, 1994)

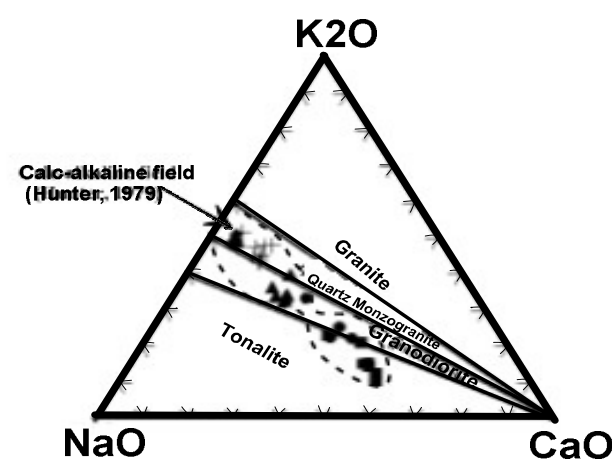

Fig.19: $\mathrm{K}_{2} \mathrm{O}-\mathrm{Na}_{2} \mathrm{O}-\mathrm{CaO}$ ternary diagram of the studied granitoid rocks (According to Condie, 1973)

granitoid rocks plot within the calc-alkaline field, (Fig.20). The alumina saturation ternary diagram $\left(\mathrm{Al}_{2} \mathrm{O}_{3}-\mathrm{K}_{2} \mathrm{O}+\mathrm{Na}_{2} \mathrm{O}-\mathrm{CaO}\right)$ of Shand (1951), (Fig.21) shows that all the data points of the granitoid rocks of the studied area plot in the peraluminous field. By using the binary relation between $\mathrm{K}_{2} \mathrm{O}$ and $\mathrm{Na}_{2} \mathrm{O}$ to discriminate between I- and S-type granites by Hine et al. (1978), the concerned granites plot mainly in the I-type granite field (Fig.22).

\section{Tectonic Setting}

A number of major as well trace elements variation diagrams have been used for the discrimination and tectonic settings of the granitic rocks.

Figures $(23 \& 24)$ show the ternary diagrams of normative Qz-Ab-Or system illustrating the temperature isotherms and pressure isobars respectively. All the granitoids samples plot near the cotectic minima at $\mathrm{pH}_{2} \mathrm{O}>5 \mathrm{~kb}$ except for the tonalites and granodiorites plot $\approx 5 \mathrm{~kb}$, (Tuttle and Bowen, 1958). Also, the figures indicate that the magmas of the batholiths crystallized under temperature ranging between $800^{\circ} \mathrm{C}$ and $840^{\circ} \mathrm{C}$ for the different granitic rocks.

The Nb-Y discrimination diagram of Pearce et al., (1984) as shown in (Fig.25) clears that 


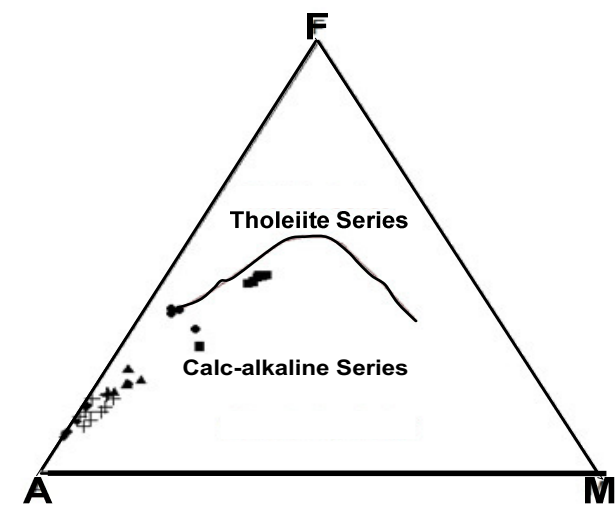

Fig.20: AFM ternary diagram of the studied granitoid rocks (According to Irvine and Baragar, 1971)

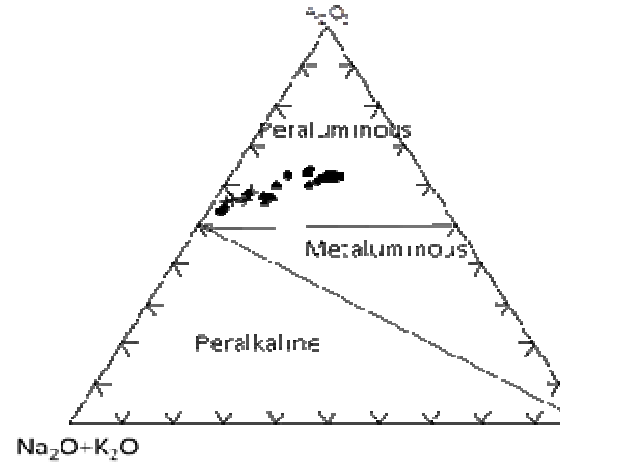

Fig. 21: $\mathrm{Al}_{2} \mathrm{O}_{3}-\left(\mathrm{Na}_{2} \mathrm{O}+\mathrm{K}_{2} \mathrm{O}\right)-\mathrm{CaO}$ ternary diagram of the studied granitoid rocks (According to Shand, 1951

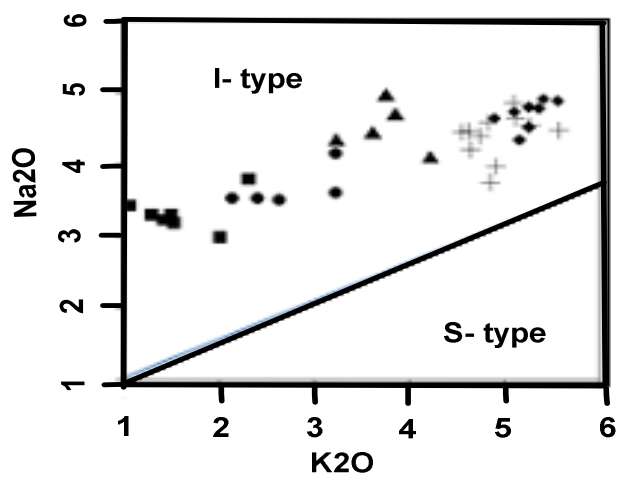

Fig. $22: \mathrm{K}_{2} \mathrm{O}-\mathrm{Na}_{2} \mathrm{O}$ binary diagram of the studied granitoid rocks (According to Hine et al., 1978)

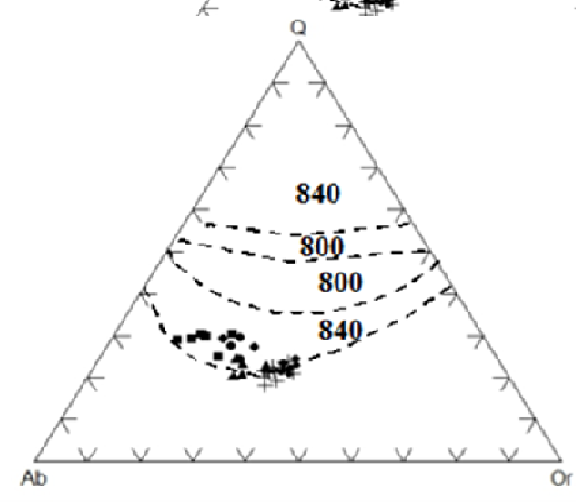

Fig.23: Ternary diagram ofQz-Ab-Orillustrating temperature isotherms of the studied granitoid rocks (According to Tuttle and Bowen, 1958)

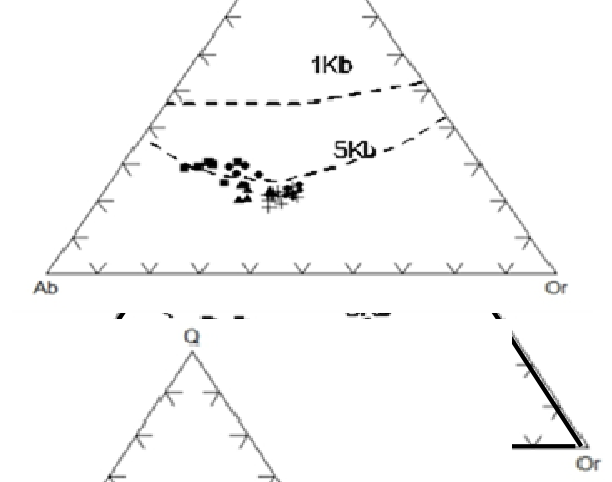

Fig.24: Ternary diagram of Qz-Ab-Or illustrating pressure isobars of the studied granitoid rocks ( According to Tuttle and Bowen, 1958)

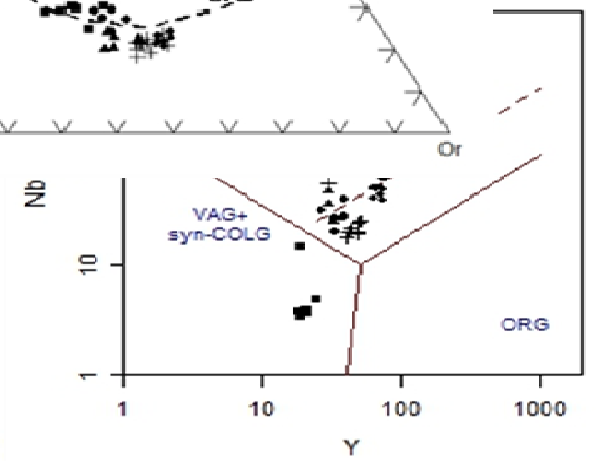

Fig.25: Nb-Y binary diagram (According to Pearce et al., 1984) 
the tonalite samples plot in the VAG+SynCOLG field while, the rest of studied samples plot in the WPG field. The authets used the binary $\mathrm{Rb}-\mathrm{Y}+\mathrm{Nb}$ diagram to separate the VAG filed from the Syn-COLG granite field (Fig.26). The studied granitic rock samples plotted in the WPG except the tonalite samples plotted in VAG field. According to Pearce (1996), all the studied rock samples plotted in Post-COLG field.

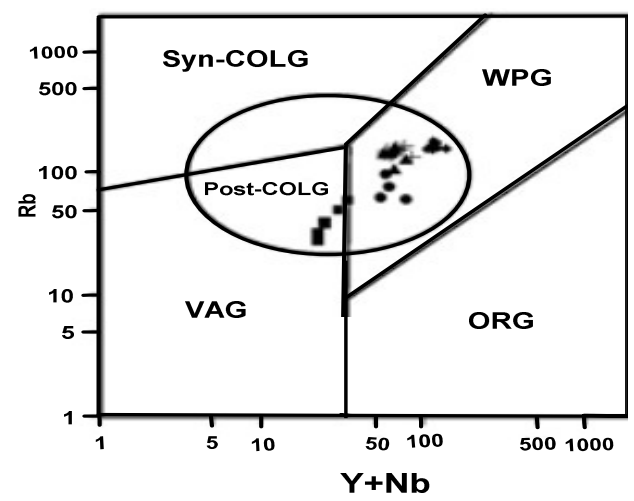

Fig. 26: $\mathrm{Rb}-\mathrm{Y}+\mathrm{Nb}$ binary diagram (According to Pearce, 1996).

\section{Petrogenesis}

The variations and inter-element relationships between $\mathrm{K}, \mathrm{Rb}, \mathrm{Sr}$, and $\mathrm{Ba}$ can be used to identify the nature of the magmatic liquids from which the studied rock types originated as well as the magmatic processes involved in magma generation.

Gast (1965) and Heier (1973), showed that the $\mathrm{K} / \mathrm{Rb}$ ratios in the igneous rocks derived from lower crustal or upper mantle materials are very high (700-1500). On the other hand, Taylor (1965) reported that the average $\mathrm{K} / \mathrm{Rb}$ ratios are 253.52 for tonalite and granodiorite and 202.78 for monzogranite and syenogranite.

Figure (27) shows the variations between $\mathrm{K}$ and $\mathrm{Rb}$ in the studied tonalite, granodiorite, monzogranite and syenogranite. The data plotting of the studied samples are mostly scattered between the $\mathrm{K} / \mathrm{Rb}$ lines of 100 and 350 .

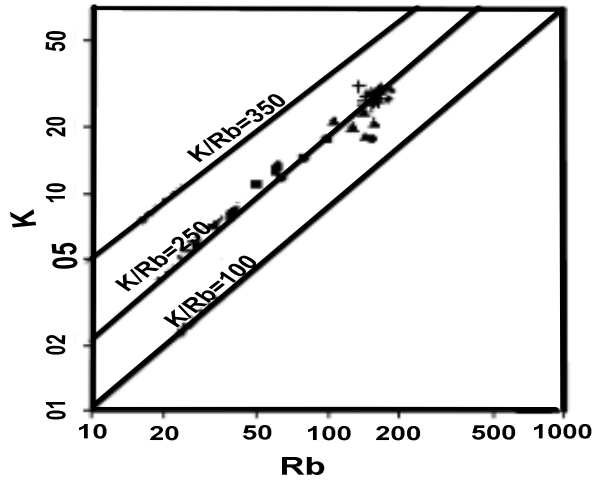

Fig.27: K-Rb binary diagram (According to Heier, 1973)

Figure (28) shows the K-Ba variation diagram. Mason (1966) reported that the average $\mathrm{K} / \mathrm{Ba}$ ratio for the crust is 65 . The plotting shows that the studied syenogranite and alkalifeldspar granite samples are plotted above $\mathrm{K} /$ $\mathrm{Ba}$ ratio line $>65$ declaring that they have $\mathrm{K} /$ $\mathrm{Ba}$ ratios more than the average crustal ratio, whereas the monzogranite samples plot between $\mathrm{K} / \mathrm{Ba}$ ratio line 28-49. The tonalite and granodiorite samples plot around $\mathrm{K} / \mathrm{Ba}$ ratio line less than 30 . The average crustal $\mathrm{Ba} / \mathrm{Rb}$ value given by Mason (1966) is 4.4 for tonalite and granodiorite and 4.1 for monzogranite and syenogranite. The $\mathrm{Ba} / \mathrm{Rb}$ variation diagram (Fig.29), shows that the studied tonalite, granodiorite and monzogranites plot around the $\mathrm{Ba} / \mathrm{Rb}$ ratio line more than 4 indicating $\mathrm{Rb}$ depletion while the studied syenogranite and alkali feldspar granite samples occupy a separate field which plot between $\mathrm{Ba} / \mathrm{Rb}$ ratio lines 0.1 and 1 indicating $\mathrm{Rb}$ enrichment. It is evident of figure (29) that Abu Marw granitic varieties follow the fractional crystallization trend of Nedelec et al., (1995).

$\mathrm{The} \mathrm{Rb} / \mathrm{Sr}$ ratio increases in the granitic liquid by the presence of feldspars, and decreases by the presence of biotite in the residue, (Hanson, 1978). The $\mathrm{Rb} / \mathrm{Sr}$ variation diagram, (Fig.30), shows a slightly decreasing trend from the alkali feldspar granites towards tonalite indicating that variation of $\mathrm{Rb}$ and $\mathrm{Sr}$ 


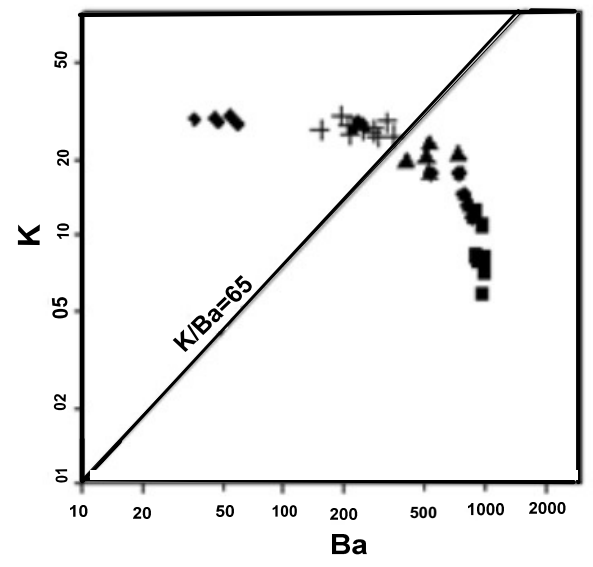

Fig.28: K-Ba binary diagram (According to Mason,(1966)

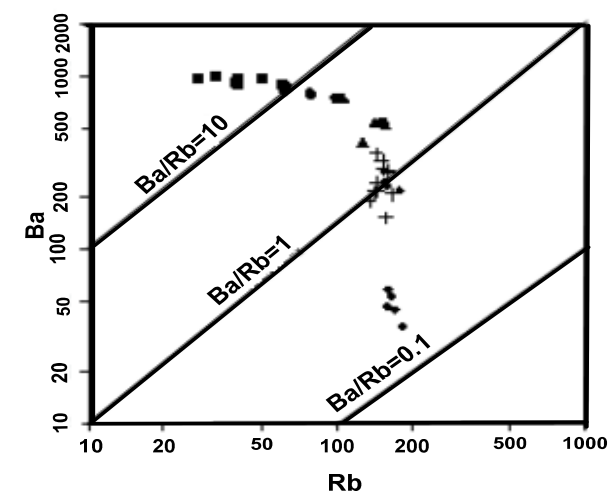

Fig.29: Ba-Rb binary diagram (According to Mason, 1966)

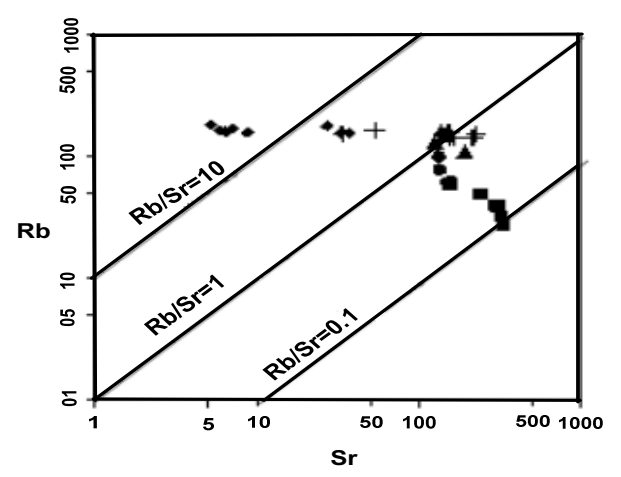

Fig.30: Sr-Rb binary diagram (According to Mason,1966) was controlled by magmatic processes. The studied tonalite, granodiorite, monzogranite and syenogranite samples plot between the $\mathrm{Rb} / \mathrm{Sr}$ ratio lines 0.1 and 1 except two samples of syenogranite are plotted above the $\mathrm{Rb} / \mathrm{Sr}$ ratio line 1 whereas the alkali feldspar granite samples are plotted above the $\mathrm{Rb} / \mathrm{Sr}$ ratio line 1 except five samples which plot above the $\mathrm{Rb} / \mathrm{Sr}$ ratio line 20 .

The $\mathrm{Rb}-\mathrm{Sr}$ variation diagram also shows that the crustal depths at which the studied tonalite, granodiorite, monzogranite, syenogranite and alkali feldspar granite were formed, (Condie, 1973), (Fig.31). From the figure, the studied tonalite, granodiorite and monzogranites were formed at depths on the border of $30 \mathrm{~km}$ or more, while the studied syenogranite and alkali feldspar granite were formed at depths more than 30 kilometers.

\section{RARE EARTH ELEMENTS}

The average rare earth element concentrations with normalized ratios and parameters (Anders and Grevesse, 1989) of G. Abu Marw granites are presented in Table (3). The studied tonalite and granodiorite samples have $\Sigma$ REE lower than the average REE values (250ppm) of granitic rocks as given by Herrmann (1970), while the monzogranite, syenogranite and alkali feldspar granite samples have $\Sigma$ REE above the average REE values

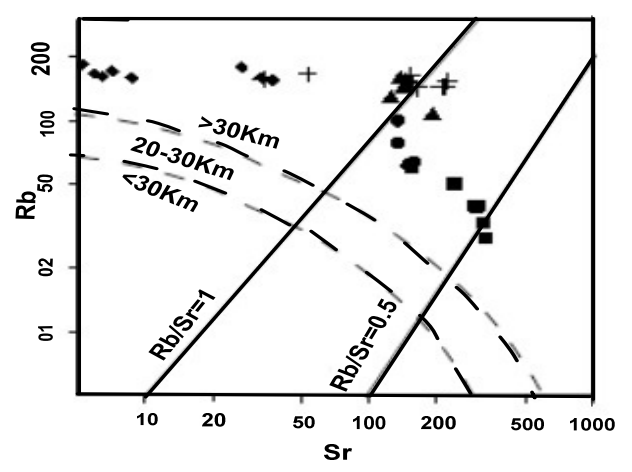

Fig.31: $\mathrm{Rb}-\mathrm{Sr}$ of the studied granitoid rocks (According to Condie, 1973) 
of granitic rocks. The relative abundances of some accessory minerals such as monazite and allanite (LREEs) hornblende ( $\mathrm{Sm}, \mathrm{Gd}-\mathrm{Lu}$ ), apatite (all REEs), zircon and fluorite (Er-Lu) explains the increasing of $\Sigma$ REE contents in the syenogranite $($ average $=453.44 \mathrm{ppm})$ and the alkali feldspar granite (1079.9).

The $(\mathrm{La} / \mathrm{Yb})_{\mathrm{N}}$ ratio, which describes LREE/HREE fractionation, ranges from 7.75 to 15.29. The LREE fractionation ratios, expressed as $(\mathrm{La} / \mathrm{Sm})_{\mathrm{v}}$, are between 3.51 and 2.81, and the $(\mathrm{Gd} / \mathrm{Yb})_{\mathrm{N}}$ ratio, which represents HREE fractionation, varies from 1.29 to 2.97 (Table 3).

Chondrite-normalized REE patterns (Sun and McDonough, 1989) of the considered

Table 3: The average contents or the REE analysis $(\mathrm{ppm})$, in the different granitoid rocks of the studied area

\begin{tabular}{|c|c|c|c|c|c|}
\hline $\begin{array}{l}\text { Rock } \\
\text { type }\end{array}$ & Tonalite & granodiorite & Monzogranite & syenogranite & $\begin{array}{l}\text { Alkali } \\
\text { feldspar } \\
\text { granite }\end{array}$ \\
\hline $\mathrm{La}$ & 28.5 & 38.35 & 48.3 & 83.16 & 198.68 \\
\hline $\mathrm{Ce}$ & 55.5 & 56.86 & 93.67 & 204.68 & 461.24 \\
\hline Pr & 6.67 & 6.88 & 11.16 & 25.76 & 56.78 \\
\hline $\mathrm{Nd}$ & 26.9 & 26.54 & 41.54 & 90.2 & 228.84 \\
\hline $\mathrm{Sm}$ & 5.07 & 5.46 & 7.93 & 18.26 & 44.36 \\
\hline $\mathrm{Eu}$ & 0.69 & 1.08 & 0.95 & 0.79 & 4.26 \\
\hline $\mathrm{Gd}$ & 3.93 & 5.32 & 6.66 & 11.68 & 32.22 \\
\hline $\mathrm{Tb}$ & 0.55 & 0.74 & 0.96 & 1.6 & 4.22 \\
\hline Dy & 2.87 & 4.9 & 6.06 & 7.48 & 25.1 \\
\hline $\mathrm{H}_{0}$ & 0.83 & 0.98 & 1.1 & 1.28 & 2.96 \\
\hline $\mathrm{Er}$ & 1.43 & 2.64 & 3.16 & 2.98 & 10.04 \\
\hline $\mathrm{Tm}$ & 0.2 & 0.38 & 0.45 & 0.44 & 1.34 \\
\hline $\mathrm{Yb}$ & 2.07 & 2.94 & 3.46 & 4.5 & 8.78 \\
\hline $\mathrm{Lu}$ & 0.33 & 0.4 & 0.49 & 0.63 & 1.08 \\
\hline TREE & 135.94 & 153.47 & 225.89 & 453.44 & 1079.9 \\
\hline TREE+Y & 155.95 & 186.47 & 259.89 & 497.44 & 1148.9 \\
\hline LREE & 122.64 & 134.09 & 202.6 & 422.06 & 989.9 \\
\hline HREE & 8.04 & 12.04 & 14.63 & 21.55 & 65.8 \\
\hline MREE & 5.26 & 7.34 & 8.66 & 9.83 & 24.2 \\
\hline$(\mathrm{La} / \mathrm{Yb})_{\mathrm{N}}$ & 7.754847 & 8.814621 & 9.433148 & 12.48785 & 15.29133 \\
\hline$(\mathrm{La} / \mathrm{Sm})_{\mathrm{N}}$ & 3.519026 & 3.420981 & 3.833715 & 2.866551 & 2.819087 \\
\hline$(\mathrm{Gd} / \mathrm{Yb})_{\mathrm{N}}$ & 1.289513 & 1.466542 & 1.560014 & 2.103588 & 2.974139 \\
\hline$(\mathrm{Tb} / \mathrm{Yb})_{\mathrm{N}}$ & 0.952115 & 1.076237 & 1.186366 & 1.520307 & 2.055141 \\
\hline$\left(\mathrm{Sm} / \mathrm{H}_{0}\right)_{\mathrm{N}}$ & 2.250336 & 2.052505 & 2.655817 & 5.255432 & 5.520996 \\
\hline LREE/HRRE & 23.31559 & 18.26839 & 23.39492 & 42.93591 & 40.90496 \\
\hline$(\mathrm{La} / \mathrm{Y})_{\mathrm{N}}$ & 8.689024 & 5.343541 & 8.709328 & 11.58719 & 17.65312 \\
\hline
\end{tabular}

granites (Figs.32-36) display a gull-wing shape, characterized by large to moderately fractionated patterns and high LREE relative to the MREE and HREE contents. Furthermore, the studied rocks have a steadily decreasing $\mathrm{Eu} / \mathrm{Eu}^{*}$ values from the tonalite $(0.56$, on average) to the alkali feldspar granite $(0.29$, on average) with simultaneous increase in the $\Sigma$ REE contents (Table 3 ).

The syenogranite and alkali feldspar granite have high REE abundances ( $\Sigma$ REE $=453.44-1079.9 \mathrm{ppm}$ ). The average LREE concentrations of the syenogranites (422.06ppm) were usually higher than the average concentrations of both the MREE (9.83 ppm) and HREE (24.2 ppm; Table 3). The syenogranite exhibits REE pattern characterized by a steep negative slope from $\mathrm{Ce}$ to Eu, a partially or nearly flat HREE signa-

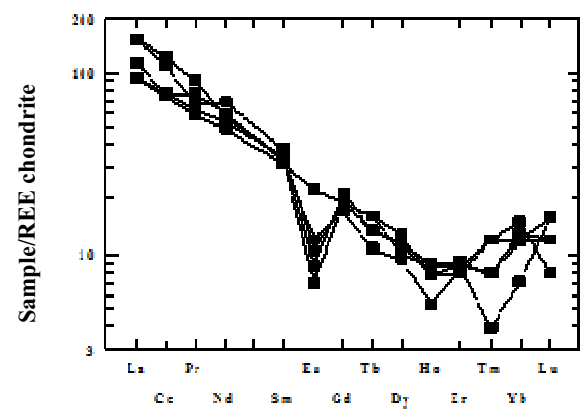

Fig.32: Chondrite-normalized REE patterns of tonalite (According to Sun and McDonough, 1989) Symbols as in Fig. (2).

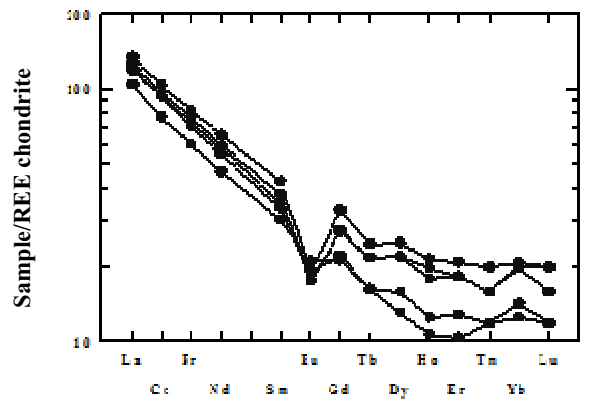

Fig.33:Chondrite-normalized REE patterns of granodiorite (According to Sun and McDonough, 1989) Symbols as in Fig. (2). 


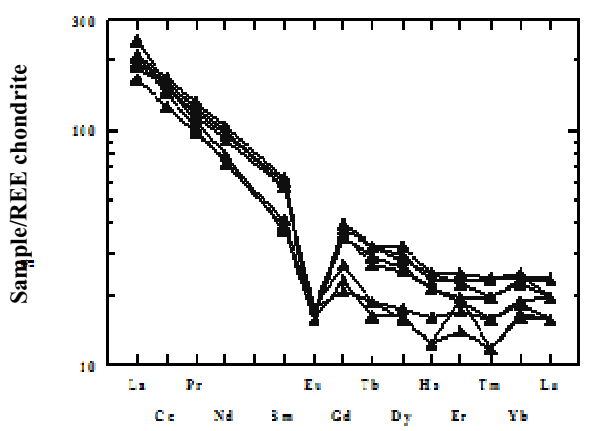

Fig.34:Chondrite-normalized REE patterns of monzogranite (According to Sun and McDonough, 1989) Symbols as in Fig. (2).

ture, a high negative Eu anomaly (0.37-0.81) and a negative to slightly positive Ce anomaly (0.78-1.10). The syenogranite has an average $(\mathrm{La} / \mathrm{Yb})_{\mathrm{N}}$ ratio 12.49 and $(\mathrm{La} / \mathrm{Sm})_{\mathrm{N}}$ ratio 2.87 with $(\mathrm{Gd} / \mathrm{Yb})_{\mathrm{N}}$ average ratio 2.11 (Table 3, Fig. 35).

The average $\Sigma$ REE value the alkali feldspar granite is $1079.9 \mathrm{ppm}$. It displays enrichment in LREE (989.9 ppm) with depletion in MREE (24.2 ppm) and HREE (65.8 ppm). The alkali feldspar granite have REE patterns which remarkably show more or less closely similar behavior to that of the most primitive granite of the syenogranite but with strong Eu anomaly (0.11-0.46) and slightly positive Ce anomaly (0.97-1.21). The normalized average ratio show $(\mathrm{La} / \mathrm{Yb})_{\mathrm{N}} 15.29$ and $(\mathrm{La} / \mathrm{Sm})_{\mathrm{N}}$ average ratio 2.82 with $(\mathrm{Gd} / \mathrm{Yb})_{\mathrm{N}}$ average ratio 2.97 (Table 3, Fig. 36).

In order to investigate the relative content and the fractionation trends of the REEs in the studied granites (Table 3), their contents and averages are normalized to chondrite, (Boynton, 1984), (Fig.37). In general terms, the REEs content averages and normalized patterns are quite similar and display parallel fractionated common features. They all show continuous slop with developed enrichment trend of LREEs (range from 90 to $600 \mathrm{x}$ chondrite in tonalite-alkali feldspar granite, $\mathrm{La}$ section) relative to HREEs (range from 10 to

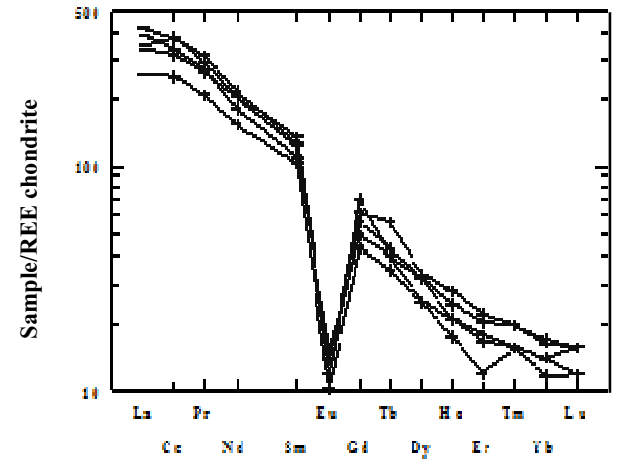

Fig.35:Chondrite-normalized REE patterns of syenogranite (According to Sun and McDonough, 1989) Symbols as in Fig. (2).

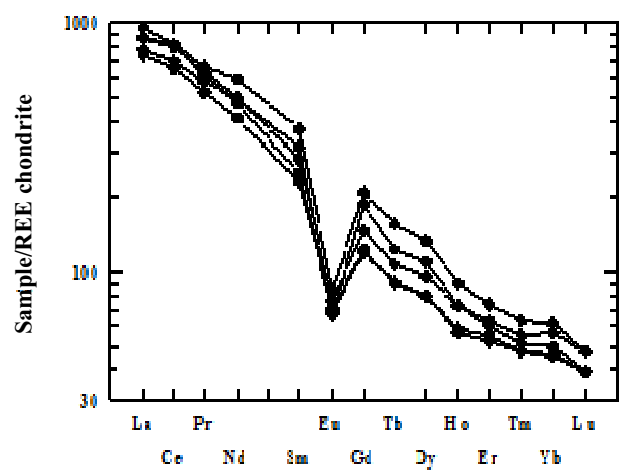

Fig.36:Chondrite-normalized REE patterns of alkali feldspar granite (According to Sun and McDonough, 1989) Symbols as in Fig. (2).

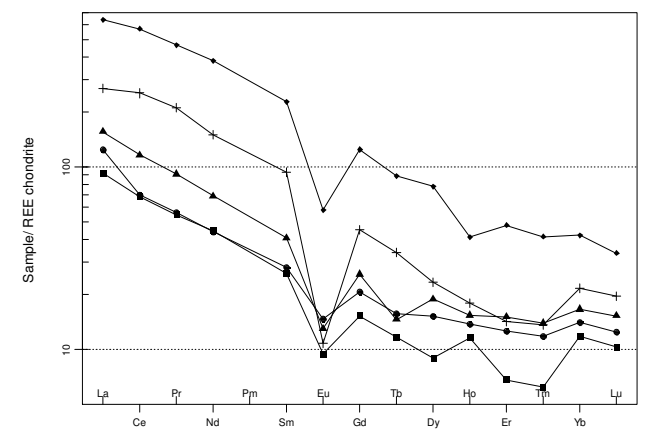

Fig.37: normalized to chondrite (According to Boynton, 1984) 
$30 \mathrm{x}$ chondrite, $\mathrm{Lu}$ section). The patterns show positive to negative $\mathrm{Eu}$ anomalies ranging from +1.65 to -0.64 in tonalite and syenogranite, respectively. The tonalite-alkali feldspar granite system have REEs content showing constructive enrichment ( $\sum$ REEs range from $135.9 \mathrm{ppm}$ in tonalite to $1079.9 \mathrm{ppm}$ in alkali feldspar granite) with differentiation trend generally presented in approximately chondritic proportions .

There are some constraints concerning the peterogenetic processes responsible for the evolution of the studied rocks. This demands the prediction of whether the whole granitic rock sequences of Gabal Abu-Marw had evolved from tonalites to alkali feldspar granites from chemically similar magma source regions. The application of $\mathrm{Al}_{2} \mathrm{O}_{3} / \mathrm{TiO}_{2}-\mathrm{TiO}_{2}$ diagram (Fig.38) as suggested by Sun and Nesbitt (1978) indicates that the studied granitic rocks resulted from a continuity of magma evolution, whereas syenogranites and the alkali feldspar granites follow a relatively different evolution trend. The high $\mathrm{TiO}_{2}$ content characters the least fractionated varieties (tonalites), while the lower $\mathrm{TiO}_{2}$ content represents the more fractionated varieties (syenogranites and alkali feldspar granites).

The correlations among major and trace elements (Fig.2) refer to the strong associations of strongly incompatible elements such as the HFSE, $\mathrm{Y}, \mathrm{Ga}$ and $\mathrm{Rb}$ with $\mathrm{SiO}_{2}$. The negative correlation between $\mathrm{Sr}$ and $\mathrm{SiO}_{2}$ suggests that the various rock units are controlled by magmatic differentiation processes.

The REEs indices of the investigated five granitic rock units are plotted against the differentiation index of the magmatic system (e.g. $\mathrm{SiO}_{2}$ ). The petrogenetic significance of the REEs content, degree of fractionation and trends and the pattern anomalies throughout the system is illustrated in the following concluded remarks:

1- The variation in $\sum$ REEs and fractionation trends as measured by the ratios $(\mathrm{La} / \mathrm{Yb})_{\mathrm{N}}$ $(\mathrm{La} / \mathrm{Sm})_{\mathrm{N}}$ and $(\mathrm{Gd} / \mathrm{Yb})_{\mathrm{N}},($ Fig.39) provide evi-

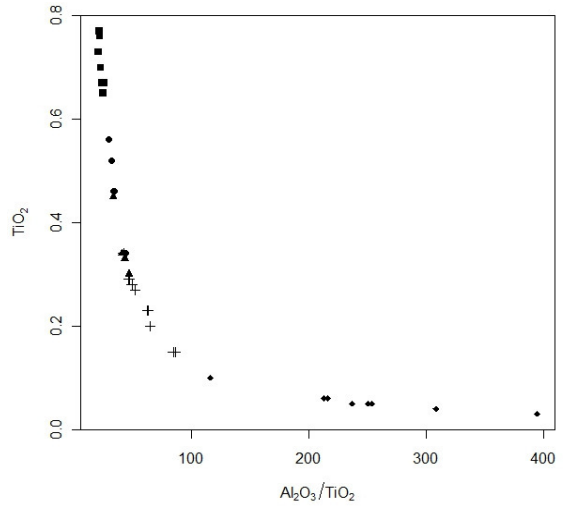

Fig.38: $\mathrm{Al}_{2} \mathrm{O}_{3} / \mathrm{TiO}_{2}-\mathrm{TiO}_{2}$ diagram of the studied granitoid rocks(According to Sun and Nesbitt, 1978). Symbolss as in Fig.(2).

dences for telescoping into single comagmatic differentiated series. The REEs content shows progressive constructive enrichment reaching highest content in syenogranites and alkali feldspar granites (Fig.39a). The least differentiated rock type, tonalite, has fair degree of fractionation trend ['r' ratio $<1 ;(\mathrm{La} / \mathrm{Yb})_{\mathrm{N}}<1$, (Fig.39b). These points to limited crustal contamination of mantle melt source having MORB proportions composition. The progressive uniform fractionation trends throughout the series (Fig.39b) refer to normal magmatic fractional crystallization processes controlling their petrogenetic history. The modal involves distinctive feldspar fractionation signatures throughout the series such as LREEs content and fractionation trend (Fig.39); $\mathrm{Eu} / \mathrm{Eu}^{*}, \mathrm{Ca}^{2+}$ and $\mathrm{Sr}^{2+}$ systematic inter-element relation (Fig.39c). In addition, the systematic of REEs geochemical behavior (Fig.39) rule out extensive alteration and large scale crustal contamination and/or magma mixing, since dramatic variation changes is not evident throughout the petrogenetic history of the rock unit series. Moreover, each rock unit of the series carries its own REEs geochemical signature inventory referring to mantle melt source of a comagmatic REEs patterns molded by fractional processes.

2- The MREEs content and fractionation 

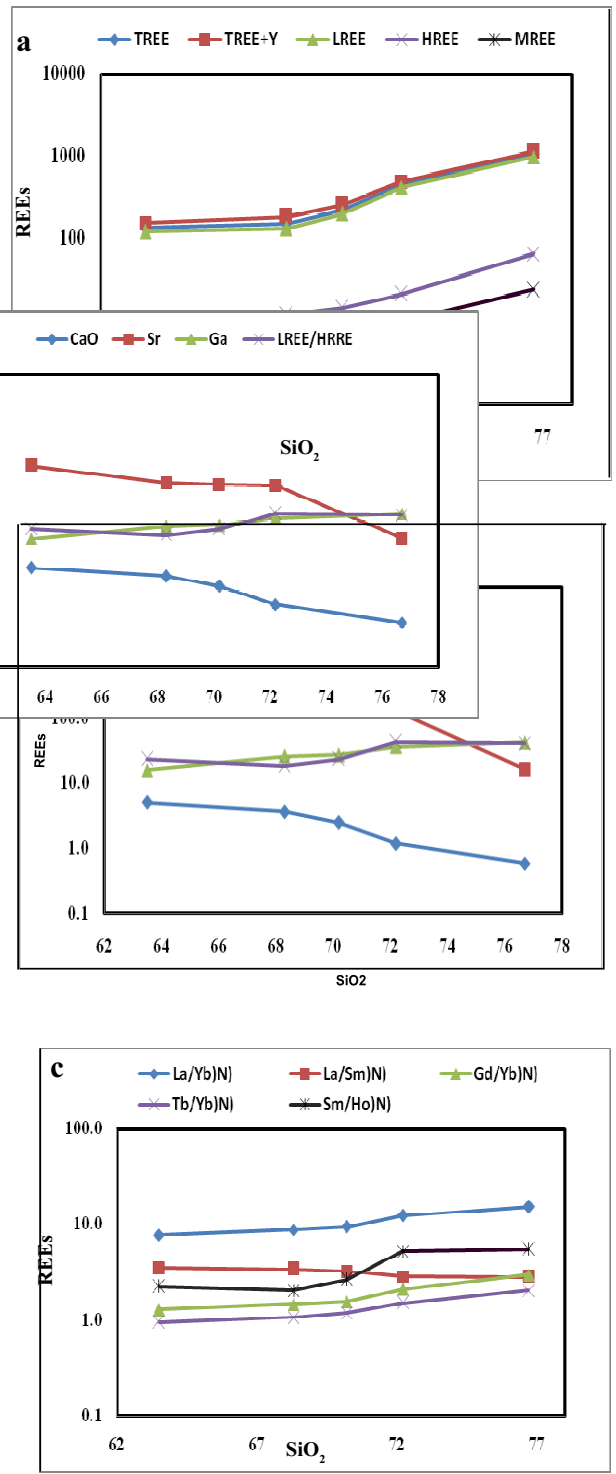

Fig.39: The REEs variation pattern of the studied granitoid rocks

trends $(\mathrm{Sm} / \mathrm{Ho})_{\mathrm{N}}$ show consistent variation with neighboring subgroups (Fig.39a\&b). Such conformable geochemical behavior subgroups refer to their coherent behavior in magmatic differentiation sequence and necessitate two requirements: (I) subordinate role of amphibole fractionation, which has preference incorporation of MREEs with convex upward fractionation trend (maximum at $\mathrm{Ho}$ ) in tonalite- alkali feldspar granite system (Hilyard et al., 2000), and (II) Absence of amphibolized peridotites contaminant in tonalite or amphibole-bearing cumulate xenoliths throughout the genetic history of the series. Such effects are generally abundant in oceanic arc, continental crust and the partial melting products of these rocks (Rapp, 1995).

3- In igneous environments (relative reducing conditions) europium is almost entirely present as divalent state $\left(\mathrm{Eu}^{2+}\right)$. So, unlike the rest of the REEs $\left(\mathrm{Ln}^{3+}\right)$, which are mainly associated with accessory minerals (Panahi, et al., 2000), $\mathrm{Eu}^{2+}$ partitions 20 to 100 times more efficiently in plagioclase (Condie and Hunter, 1976; Wilke and Behrens, 1999) replacing $\mathrm{Ca}^{2+}, \mathrm{Sr}^{2+}$ and $\mathrm{Na}^{+}$(Henderson, 1996). This anomalous behavior is of particular interest and makes "'Eu" acts as a sensitive indicator for destruction of plagioclase structure (since it does not reside in saussurite, sericite or illite structure), Panahi et al., (Op.Cit.). The regular uniform concomitant relationship of $\mathrm{Eu} / \mathrm{Eu}^{*}$ and $\mathrm{Ca}^{2+}$ and $\mathrm{Sr}^{2+}$ during the differentiation sequence of the system (Fig.39c) clearly refers to the limited alteration effect of plagioclase. Otherwise, the effect will yield to dramatic negativeve Eu anomaly associated with similar behavior of $\mathrm{Ca}, \mathrm{Sr}, \mathrm{K}$ and $\mathrm{Na}$. Furthermore, Nagasawa and Schnetzler, (1971) measured $\mathrm{Eu}$ and $\mathrm{Sr}$ distribution in coexisting $\mathrm{Ca}$ and $\mathrm{K}$-feldspars and concluded that $\mathrm{Eu}^{2+}$ behaves very similar much like $\mathrm{Sr}^{2+}$. The reported similar uniform geochemical behavior of $\mathrm{Eu}^{2+}$ and $\mathrm{Sr}^{2+}$ during magmatic differentiation sequence (Fig.39c, Table 3) confirm the limited transformation (chemical weathering and/or alteration) of the rock forming $\mathrm{Ca}$ and $\mathrm{K}$-feldspars into accessory phases throughout the tonalitealkali feldspar granite system.

4- The linear variations of "'r" ratios (La/ $\mathrm{Yb})_{\mathrm{N}}, \sum$ LREEs, $\sum$ MREEs and $\sum$ HREEs during differentiation sequence (Figs.39a\&b) refer to the absence of intensive effect of ac- 
cessory minerals characterized by appreciable preference incorporation of certain REEs subgroup such as allanite, xenotime, sphene, monazite and zircon (Henderson, 1984, Hanson, 1989 and Evans and Hanson, 1993). The variations of REEs indices indicate that they were ordered according to magma fractionation processes.

5- The REEs patterns show that the elements maintain their geochemical coherent behavior during the whole differentiation sequence of the system \{viz., parallelism of the patterns and straight forward behavior of the indices, Fig.39a\}. So, such systematic can be modeled according to the coherent geochemical behavior of the rare earth elements and not to the stability constants of their complexes. The latter have different geochemical systematic, depending upon the legend varieties that yield different fractionation trend of the REEs patterns throughout the system. So, the system was deficient in metal legend free radicals such as $\mathrm{O}^{2}, \mathrm{OH}^{-}, \mathrm{F}^{-}, \mathrm{Cl}^{-}, \mathrm{CO}_{3}{ }^{-}, \mathrm{SO}_{4}{ }^{2-}, \mathrm{PO}_{3}{ }^{3+}$ etc.. and hence the system is non-mineralized. Since such metal legend volatile agents act the main role in ore genesis (via, mobilization, concentration and transportation of metallogenic metals and ore deposition as result of degassing (decomplexing) of the ore-bearing hydrothermal precipitation system).

\section{Distribution of $U$ and $T h$ in Different Granite Rocks}

A total number of 28 rock samples representing the different rock type described before, as well as 8 from the sites of radioactive anomalies were collected, to study the distribution of uranium and thorium, Tables (4\&5). These samples include tonalite 5 samples, granodiorite 5 samples, monzogranite 5 samples syenogranites 8 samples, and alkali feldspar granites 5 samples, Table (4). The U and Th contents were determine using ICPMS techniques in Acma Lab., Canada for the different granitoid rocks in the studied area and the radioactive sites samples. The identification of the radioactive minerals causing the high radioactivity in the anomalous sites in the syenogranites was carried out using X-ray diffraction techniques.

Uranium and thorium trend to concentrate in the residual phases and enter the accessory minerals such as zircon, monazite, xenotime, allanite, apatite and sphene. Also, they may form minerals of their own such as uraninite, thorite and uranothorite (Rogers and Adams, 1969). It has been shown that the accessory minerals and their sequence of crystallization play a major role in controlling the geochemical behavior of $\mathrm{U}$ and $\mathrm{Th}$ in silicate melts, (Simpson, et al., 1979). The early crystallization of thorite and / or monazite would lead to significant U-enrichment in residual fluids. On the other hand, the early crystallization of zircon and / or apatite would lead to Th-enrichment in the residual fluids; Pagel (1982) showed that $\mathrm{U}$, Th and Hf are zoned in zircon from many granitic rocks. The crystallization of uranothorite does not have any fractionation effect on $U$ and Th. The presence of secondary supergene uranium minerals indicates that such granitic rocks were subjected to active hydrothermal convective cells and the accessory minerals controlled the fractionation of $U$ and $\mathrm{Th}$ in the granitoid rocks of the studied area. It is evident that zircon and apatite crystallized earlier and led to the enrichment of Th in the residual fluids. This probably created the abnormal concentrations of Th-bearing minerals in the radioactive sites.

\section{The Anomalous Radioactive Sites}

Two sites with anomalous high radioactivity were discovered associated with Um Arka syenogranites; one in the pegmatite veins and the other in sheared zone within the granite itself, Table (5). The pegmatites associated with the syenogranites in Um Arka occur in the northwest periphery of Gabal Um Arka as small four dyke-like bodies striking mainly in the E-W direction and range from 20-50 meter in length and from $0.3-0.5 \mathrm{~m}$ in width. The radioactive anomalies in Gabal Um Arka itself are mainly associated with the sheared 
ADEL H. EL-AFANDY et al.

Table 4: The $\mathrm{U}$ and $\mathrm{Th}$ contents in the different granites.

\begin{tabular}{|c|c|c|c|}
\hline Sample No. & Rock Type & U(ppm) & Th(ppm) \\
\hline 1 & Tonalite & 0.5 & 2 \\
\hline 2 & Tonalite & 1.6 & 2.5 \\
\hline 3 & Tonalite & 1.7 & 3.3 \\
\hline 6 & Tonalite & 1 & 3.8 \\
\hline 7 & Tonalite & 2.5 & 3.5 \\
\hline Average & Tonalite & 1.4 & 3 \\
\hline 46 & Granodiorite & 1.7 & 8.3 \\
\hline 47 & Granodiorite & 2.1 & 8.7 \\
\hline 48 & Granodiorite & 1.4 & 5.4 \\
\hline 49 & Granodiorite & 1.5 & 7.8 \\
\hline 54 & Granodiorite & 2.3 & 8.5 \\
\hline Average & Granodiorite & 1.8 & 7.7 \\
\hline 51 & Monzogranite & 2 & 15.4 \\
\hline 52 & Monzogranite & $1 . \overline{8}$ & 13.6 \\
\hline 53 & Monzogranite & 2 & 16.5 \\
\hline 55 & Monzogranite & 2.3 & 15.3 \\
\hline 56 & Monzogranite & 2.6 & 14.4 \\
\hline Average & Monzogranite & 2.14 & 15.04 \\
\hline 27 & Syenogranite & 6.2 & 22.7 \\
\hline 28 & Syenogranite & 8.1 & 24.8 \\
\hline 29 & Syenogranite & 9.6 & 34.6 \\
\hline 31 & Syenogranite & 4.4 & 18.5 \\
\hline 32 & Syenogranite & 4.6 & 21.6 \\
\hline 33 & Syenogranite & 3.7 & 17.7 \\
\hline 34 & Syenogranite & 4.2 & 20.7 \\
\hline 35 & Syenogranite & 4.5 & 19.1 \\
\hline Average & Syenogranite & 5.6 & 22.46 \\
\hline $\begin{array}{l}\text { Av. Low Ca- granite after Turekian and } \\
\text { Wadepohl(1961) }\end{array}$ & & 3 & 17 \\
\hline Av.high Ca- granite after Turekian and & & & \\
\hline Wadepohl(1961) & & 3 & 8-5 \\
\hline Av. Granite after Clark et. al., (1966); & & & \\
\hline Rogers and Adams (1969) & & 5 & $18-20$ \\
\hline 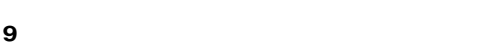 & $\begin{array}{r}\text { Alk.feld. } \\
\text { granite }\end{array}$ & 2.7 & \\
\hline 11 & Alk.feld. granite & 2.3 & \\
\hline 13 & Alk.feld. granite & 1.4 & \\
\hline 14 & Alk.feld. granite & 2.5 & \\
\hline 16 & Alk.feld. granite & 1.7 & \\
\hline $\begin{array}{l}\text { Average } \\
\text { Alkali granite after Roger and Adams } \\
\text { (1969) }\end{array}$ & Alk.feld. granite & 2.12 & \\
\hline
\end{tabular}

Table 5: $\mathrm{U}$ and $\mathrm{Th}$ contents and $\mathrm{Th} / \mathrm{U}$ ratios at the radioactive sites

\begin{tabular}{lrrrr}
\hline Sample No. & Rock type & U & Th & Th/U \\
\hline 1 & Pegmatite & 10 & 29 & 2.9 \\
2 & Pegmatite & 16 & 32 & 2 \\
3 & Pegmatite & 19 & 75 & 3.95 \\
4 & Sheared pink granites & 10 & 1200 & 120 \\
5 & Sheared pink granites & 16 & 210 & 13.13 \\
6 & Sheared pink granites & 34 & 80 & 2.35 \\
7 & Sheared pink granites & 418 & 360 & 0.86 \\
8 & Sheared pink granites & 705 & 417 & 0.59 \\
\hline
\end{tabular}

zone, aligned along E-W direction. The highest two radioactive anomalies are located in the intersection of three major fractures striking $\mathrm{N} 50^{\circ} \mathrm{E}, \mathrm{E}-\mathrm{W}$ and $\mathrm{N} 60^{\circ} \mathrm{W}$.Hydrothermal alteration products are observed in these anomalies especially hematite, limonite and manganese oxides. The secondary uranium minerals (uranophane) are observed in this anomaly.

The heavy minerals fraction was separated from pegmatite samples and from the radioactive syenogranites in Gabal Um Arka. The radioactive minerals were identified by using XRD-techniques. The results show 
that the radioactive minerals in the pegmatites are mainly zircon and fluorite, while in the sheared granites uranophane as secondary minerals and zircon, allanite, xenotime and uranothorite which are known as $\mathrm{U}$ and $\mathrm{Th}$ bearing minerals.

\section{SUMMARY AND CONCLUSIONS}

The Abu Marw area is mainly covered by Late Proterozoic igneous and metamorphic rocks. These basement rocks are unconformably overlain by upper Cretaceous Nubian sandstone in the western and northern parts of the area. From the field investigations and petrographic description, the granitoid rocks in the studied area can be divided from the oldest to tonalite, granodiorite, monzogranite, syenogranite and alkali feldspar granite.

The tonalite rocks form peripheral phase exposed in curvilinear ridges along the northeastern and eastern part of batholiths. The tonalites are invaded by quartz feldspar porpherite dykes and some of them intersect each other. The granodiorite rocks form low relief hillocks occupying the eastern central part of the batholith and the north western part of the mapped area. These rocks are oriented in ENE, N-S and NW directions. The monzogranites encountered in the central part of the granitic batholith. They surround the tonalites and granodiorites. They cutted by NNW, NW, E-W and ENE faults. The monzogranites form a continuous curvilinear mountains range trending E-W and scattered group of circular or oval shaped hills in the northwestern part of the mapped area. Syenogranites constitute the southern part of the mapped area. They cutted by wadi Um Arka and Wadi Um Ashara.These rocks cutted by NW and $\mathrm{E}-\mathrm{W}$ faults. These rocks form a continuous mountain trending E-W and a scattered group of oval shape in the southwestern part of the mapped area. Alkali feldspar granites constitute a small area encountered in the central part of the mapped area. They have curse linear isolated masses. The alkali feldspar gran- ites have low to moderate elevated mountains cutted by wadi Abu Marw.

Abu Marw granitoid batholith comprises a co-magmatic calc alkaline I-type peraluminous suite of rocks. The variations of some major and trace elements with $\mathrm{SiO}_{2}$ suggest a crystal fractionation model.

The tonalite and granodiorite, rocks probably evolved within a continental arc/continental collision environment, while the monzogranite, syenogranite and alkali feldspar granite rocks evolved in within plat environment.

The studied tonalite and granodiorite rocks have $\Sigma$ REE lower than the average REE values (250ppm) of granitic rocks, while the monzogranite, syenogranite and alkali feldspar granite rocks have $\Sigma \mathrm{REE}$ above the average REE values of granitic rocks. Chondrite-normalized REE patterns of the considered granites display a gull-wing shape, characterized by large to moderately fractionated patterns and high LREE relative to the MREE and HREE contents. Furthermore, the studied rocks have a steadily decreasing $\mathrm{Eu} / \mathrm{Eu}^{*}$ values from the tonalite to the alkali feldspar granite with simultaneous increase in the $\Sigma$ REE contents.

The average contents of $U$ and $T h$ in the different granitic rocks resemble the average contents of some international equivalent rocks. The average of $U$ contents increases with differentiation. The uranium and thorium contents in the studied granitic rocks are present in the accessory minerals particularly monazite, zircon, allanite, sphene, apatite and iron oxides, The radioactive minerals in the pegmatite anomalies are mainly zircon, uranothorite and fluorite, while in the sheared granites are uranophane as secondary minerals and zircon, allanite, xenotime and uranothorite which are known as $\mathrm{U}$ and $\mathrm{Th}$ bearing minerals.

\section{REFERENCES}

Abdel Monem, A.A.; El Amin, H.; Hussein, H.A., and El-Afandy, A., 1991. Contribution to the geology, geochemistry and petrogenesis of $\mathrm{Abu}$ 
Marw - Um Arka batholiths, South Eastern Desert, Egypt. Asw.Sc. Tech. Bull. ,12.

Abdel Monem, A.A.; El Amin, H.; Hussein, H.A.; Mansour, S.I., and El-Afandy, A.,1996. Petrography and geochemistry of some basement rocks in Wadi Hadayib area South Eastern Desert, Egypt. Mineral. Soc. Egypt.

Anders, E., and Grevesse, N., 1989. Abundances of the elements; Meteoritic and solar. Geochim. Cosmochim. Acta, 53,197-214.

Armaneous, L.K; Qusa,M.E.; Gabra,S.Z.; Rashwan, A.A.; El Miligi, A.S.; Aly, H.A.; Wasef,M. B.; Khalil, M.A.; Hassan, O.A., and El Fiqi, S.A.,1977. Geology of Gabal El Nassiya district, South eastern Desert, Egypt. Internal Report, Geological Survey, Cairo, Egypt.

Boynton, W.V., 1984. Geochemistry of the rare earth elements; Meteorite studies. In:Rare Earth Element Geochemistry( Henderson, P., Ed.): Elsevier Pub. Co. Amsterdam,.63-114.

Condie,K.C.,1973. Plate Tectonics and Crustal Evolution. Pergamon Press Inc.,U.K.,310p.

Condie, K.C., and Hunter,D.R., 1976. Trace element geochemistry of Archean granitic rocks from Barbert on region, South Africa. Earth Planet. Sci. Lett., 29,389-400.

El Afandy , A.H.,1994. Geology, petrology and radioactivity of the Basement rocks in Abu Marw SED- Egypt. Ph.D. Fac. Sci.,Assiut Univ., Aswan Branch.

El Gaby, S., 1975. Petrochemistry and geochemistry of some granites from Egypt. N. Jb.Min. Abh., 124, 147-189.

El Ramly, M.F. and Akaad, M.K., 1960: The basement complex in the central Eastern Desert of Egypt between latitudes $24^{\circ} 30^{\prime}$ and $25^{\circ} 40^{\prime} \mathrm{N}$. Geol.Surv.Cairo, 8, 35p.

El Sayed, M.M. 1998: Tectonic setting and peterogenesis of the Khadabora pluton: A Late Proterozoic anorognic A-type younger granitoid in the Egyptian Shield. Chem. Erde, 58, 38-63.
El- Shazly, E.M. 1964: On the classification of the Precambrian and other rocks of magmatic affiliation in Egypt.Proc.22th.Inter.Geol.Congr. New Dehli, 10, 88-101.

El Shazly, E.M.; Farag, I.A.M. and Bassyouni, F.A., 1965: Contribution to the geology and mineralization at Abu Swayel area, Eastern Desert: Part 1.Geology of Abu Swayel area. J.Geol.U.A.R., 45-67.

El Shazly, E.M., Hashad, A.H., Sayyah, T.A., and Bassyouni, F.A., 1973: Geochronology of Abu Swayel area, South Eastern Desert, Egypt. J.Geol.U.A.R., 17, 1-18.

El Shazly, E.M.; Bassyouni, F.A., and Abdel khalek, M.L., 1975: Geology of the greater Abu Swayel area, Eastern Desert, Egypt. Jour. Geol., 19,141.

El Shatoury, H.M., Mostafa, M.E., and Nasr, F.E., 1984: Granites and granitoid rocks a statistical approach of classification. Chem. Erde, 43, 83111.

Evans, O.C. and Hanson, G.N., 1993, Accessory mineral fractionation of rare-earth element (REE) Abundances in granitoid rocks. Chem. Geol., 110, 69- 93.

Gast, P.W., 1965, Terrestrial ratio of potassium to rubidium and the composition of the Earth's mantle. Science, 147, 858-860.

Greenberg, E.K., 1981. Characteristics and origin of Egyptian younger granites. Geol.Soc.Am.Bull. part11, 92,740-840.

Hanson, G.N., 1978. Application of trace elements to the petrogenesis of igneous rocks of granitic composition. Earth Planet. Sci. Lett., 36, .2643.

Hanson, G.N., 1989. An approach to trace element modeling using a simple igneous system as an example, in the Geology and Geochemistry of Rare Earth Elements edited by Lipin and McKay, Rev. Min., 21, 79-97.

Henderson, P., 1984. Rare Earth Element Geochemistry. Elsevier, Amsterdam, 510p. 
Henderson, P. 1996. The rare earth elements: introduction and review. In: Jones A.P. (ed.) Rare earth minerals: chemistry, origin and ore deposits, Chapman and Hall, pp 1.

Herrmann, A.G., 1970. Yttrium andLanthanides: In:handbook of geochemistry (Wedpohl,K.H., ed.), Springer-Verlag, Berline, II/2,39-57.

Heier, K.S.,1973.Geochemistry of granulite facies rocks and problems of their origin, Philos. Trans.Roy.Soc.,London,seriesA,273,429-442.

Hilyard M., Nielsen R.L., Beard J.S., Patin, O., Douce, A. and Blencoe J., 2000. Experimental determination of the partitioning behavior of rare earth and high field strength elements between pargasitic amphibole and natural silicate melts. Geochim. Cosmochim. Acta, 64(6),1103-1120.

Hine, R.,Williams,I.S.,Chappella,B.W.\&White,A. J.R.,1978. Contrasts between I and S type granitoids of the Koscivsko Batholith. J.Geol.Soc. Aust.,25, 219-234.

Hume, W.F. 1935. Geology of Egypt. Vol.II part II: The fundamental Precambrian rocks of Egypt and the Sudan.Part II. The later plutonic and minor intrusive rocks. Egypt.Surv.Depart.Cairo, 301-688.

Hunter, D.R.,1979. The role of tonalite and trodhjemitic rocks In: the crustal development of Swaziland and the eastern Transvaal, South Africa( Barker,ed). TrondhjemiteDacites and related rocks. In Development in petrology,6, El Sevier Pub.Comp.

Hussein, A.A.; Ali,M.M. and El Ramly, M.F., 1982. Aproposed new classification of the granites of Egypt. J.Volc.Geoth. Res.,14,187-198.

Irvine,T.N. and Baragar,W.R.A.,1971. Aguide to chemical classification of the common volcanic rocks. Can.J.EarthSci.,8,523-548.

Kabesh, M.L., Salem, A.K.A., and El Sheshtawy, Y.A., 1987. On the chemical behavior, origin and tectonic setting of some younger granitoids, Eastern Desert, Egypt. Bull. Fac. Sci. Zagazig
Univ., 9,300-336.

Masoud S., 2012. Geochemical characteristics of some peraluminous younger granite masses, Eastern Desert, Egypt. Nuclear Sciences Scientific J., 1,1-22.

Mason,D., 1966. Principals of Geochemistry, $3^{\text {rd }}$ Edition. JhonWiley Sons, New York,610p.

Middlemost,E.A.K. ,1994. Naming materials in the magma /igneous rock system.Earth Science Reviews 37,215-224

Nagasawa, H. and Schnetzler, C.C., 1971. Partitioning of rare earth, alkali and alkaline elements between phenocyrsts and acidic igneous magma, 35, 953-968.

Nedelec, A., Stephens, W.E. and Fallick, A., 1995. The Pan-African stratoid granites of Madagascar: Alkaline magmatism in a Post-collisional extential setting. J. Petrol., N.36 (5), 13671391.

Noweir, A.; Sewifi, B.M. and Abu El Ela, A.M., 1990. Geology and petrography and petrogenesis of the Egyptian younger granites, Qatar Univ.Sci.Bull.,10, 363-393.

Noweir, A.; El Amawy, M.A.; Rashwan, A.A. and Abdel Aziz, A.M.,1996 . Geology and structural evolution of the Pan African Basement Rocks around Wadi Um Arka, Northeast Wadi Allaqi, SED, Egypt. J.Geol.Soc. Egypt, 40(2), 477-512.

Pagel, M., 1982. The mineralogy, and geochemistry of uranium and thorium and rare earth elements in two radioactive granites in the Vosges, France. Min. Mag., 46, 149-161.

Panahi, A., Young, G.M. and Rainibird, R.H., 2000. Behavior of major and trace elements (including REE) during Paleoproterozoic pedogenesis and digenetic alteration of an Archean granite near Nile Marie, Quebec, Canada. Geochem. Cosmochem., Acta, G4(13), 2199-2220.

Pearce,J.A.; Harris, N.B. and Tindle, A.G., 1984. Trace element discrimination digrams for 
the tectonic interpretation of granitic rocks. J.petrology, 25, 956-983.

Rapp, R.P., 1995. Amphibole out phase boundary in partially melted metabasalt, its control over liquid fraction and composition, and source permeability. J. Geol. Res., Solid Earth, 100, 15601-15610.

Rogers, J.J.W. and Adams, J.A.S., 1969. Uranium and thorium, In: Handbook of Geochemistry (Wedepohl,K.H.,ed.), II-3, 92-B-2 to 92-0-8 and 90-0-5 Springer Verlag.

Sabet, A.H.; Besonenko, V.V., and Pyknov, B.A., 1976. Manifestation of rare metal mineralization in the Central Eastern Desert of Egypt. Geol. Surv. Egypt, 6,223-236.

Shand, S.J.,1951. Eruptive rocks.John Wiley, New York.488p.

Simpson, P.R.; Brown, G.C.; Plant, J. and Osthle, d., 1979. Uranium mineralization and granitic magmatism in the British Isles. Phil. Trans. Roy. Soc. London, 219A, 385-412.

Streckeisen, A.,1976. Plutonic rocks:classification and nomenclature recommended by the IUGS subcommission on the systematic of igneous rocks. Geotimes, 18,26-30.
Schurmann, H.M., 1957. The Precambrian of the Gulf of Suez area, Report of $19^{\text {th }}$ international Geological congress. Algieris, 1, 115-135.

Sun, S.S. and Nesbitt, R.W., 1978. Geochemical irregularities and genetic significance of ophiolitic basalts. Geology, 6, 689-693.

Sun, S.S. and MacDonough, W.F., 1989. Chemical and isotopic systematic of ocean basalts: Implications for mantle composition and processes, In: Magmatism in the Ocean Basins(Saunders, A.D. and Norry, M.J. ,eds) . Geol. Soc. London, Spec. Publ., 42, 313-345.

Taylor, S. R., 1965. The application of trace element data to problems in petrology. Physics and Chemistry of the Earth,6, 133-213.

Tuttle, O.F. and Bowen, N.I.1958 .The origin of granite in the light of experimental studies in the system $\mathrm{NaAlSi}_{3} \mathrm{O}_{8}-\mathrm{KAlSi}_{3} \mathrm{O}_{8}-\mathrm{SiO}_{2}-\mathrm{H}_{2} \mathrm{O}$. Geol.Soc.Amer. Mem. No.74.

Wilke, M. and Behrens, H., 1999. The dependence of the partitioning of iron and europium between plagioclase and hydrous tonalite melt on oxygen fugacity. Contrib. Mineral. Petrol.,137, $102-114$

\section{جيولوجية -جيوكميائية واشعاعية الجرانيت فى منطقة أبو مرو-جنوب الصحر اء الثرقية. مصر}

$$
\text { عادل حسن الأفندي ، عبد الرحمن امبابي ، مني الحرايري }
$$

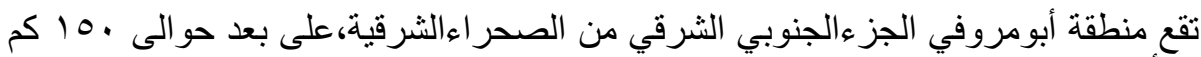

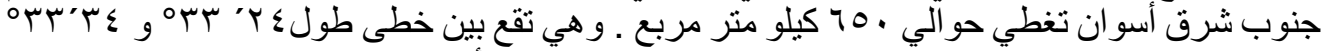

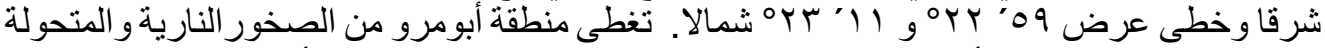
للحقب البروتيروزوي المتأخر وتعلو ها الحجر الرملي النوبي الطباثيري في الأجزاء الغربية و الثمالية

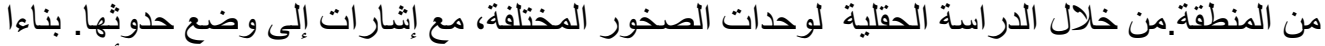

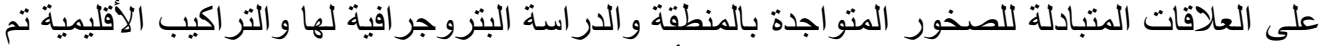

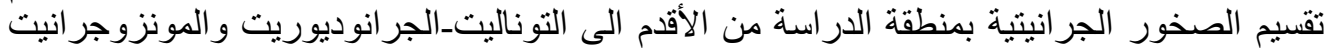

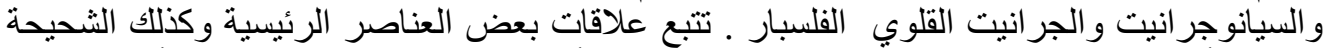

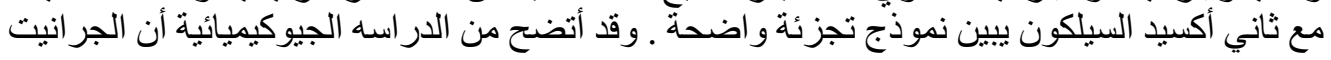


تكون من مجما كلس قلوية ذات طبيعة بير الومتية لهذه الصخور و أنها تكونت من قترة سميكة تامة

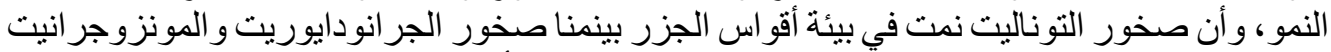

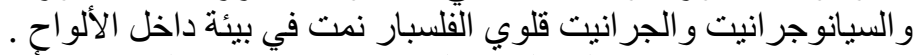

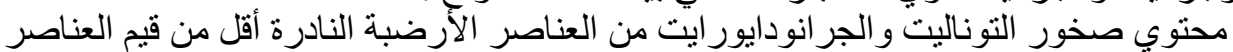

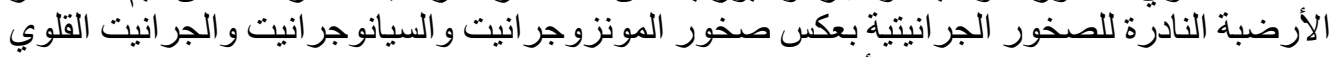

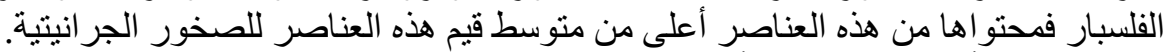

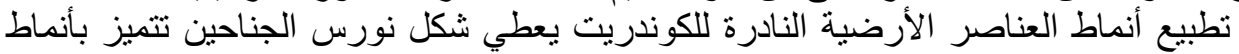

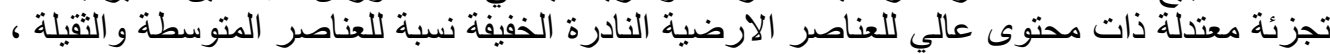
و علاوة على ذللك فان هذه الصخور تتميز بتناقص مطرد ل Eu/Eu* من التوناليت حتى الجر انيت القلوي

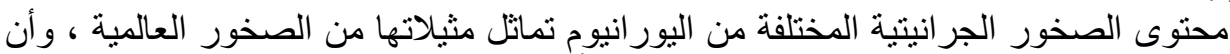
الفلسبار . معارة

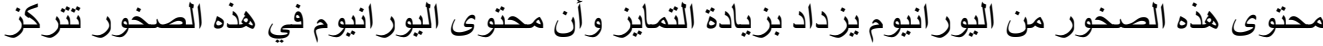

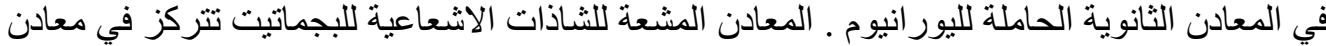

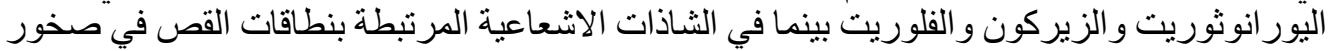

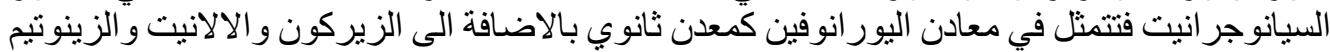

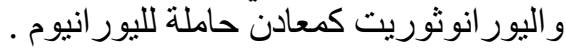

